\title{
Economic and Social Upgrading in Global Logistics
}

Link to publication record in Manchester Research Explorer

\section{Citation for published version (APA):}

Coe, N. M., \& Hess, M. (2013). Economic and Social Upgrading in Global Logistics. (Capturing the Gains Working Paper; No. 38).

\section{Citing this paper}

Please note that where the full-text provided on Manchester Research Explorer is the Author Accepted Manuscript or Proof version this may differ from the final Published version. If citing, it is advised that you check and use the publisher's definitive version.

\section{General rights}

Copyright and moral rights for the publications made accessible in the Research Explorer are retained by the authors and/or other copyright owners and it is a condition of accessing publications that users recognise and abide by the legal requirements associated with these rights.

\section{Takedown policy}

If you believe that this document breaches copyright please refer to the University of Manchester's Takedown Procedures [http://man.ac.uk/04Y6Bo] or contact uml.scholarlycommunications@manchester.ac.uk providing relevant details, so we can investigate your claim.

\section{OPEN ACCESS}




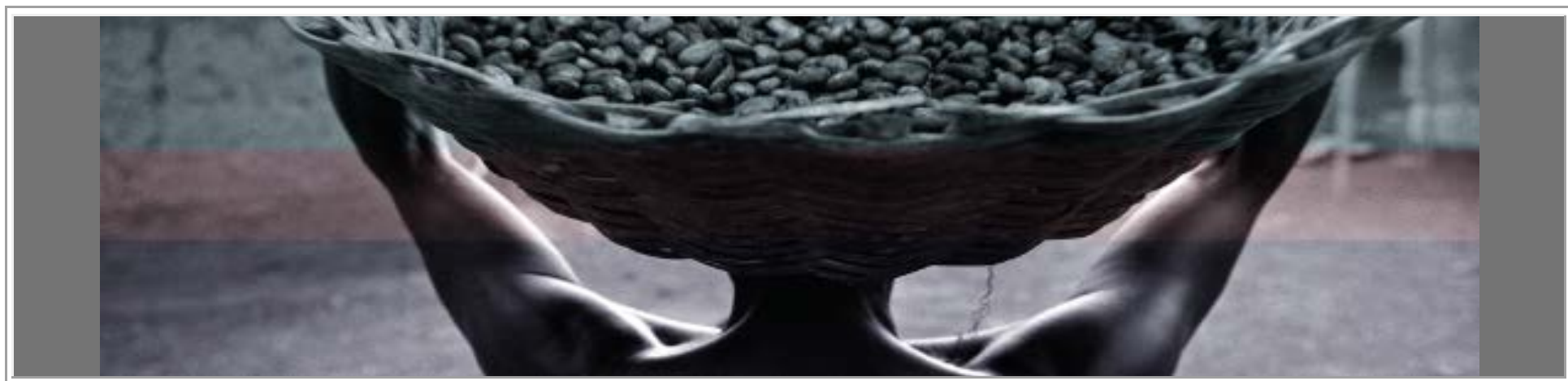

\section{CAPTURING THE GAINS}
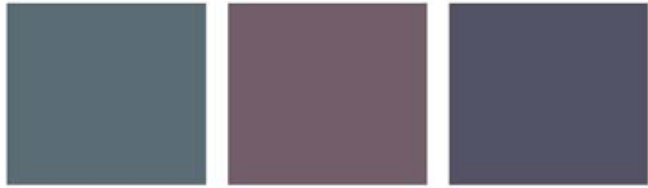

economic and social upgrading in global production networks

${ }^{1}$ National University of Singapore

Email: geonmc@nus.edu.sg

${ }^{2}$ University of Manchester

Email: martin.hess@manchester.ac.uk

Capturing the Gains 2013

ISBN: 978-1-909336-81-0
Economic and social upgrading in global logistics

Neil M. Coe ${ }^{1^{*}}$

Martin Hess ${ }^{2}$

September 2013

Working Paper 38 


\section{Abstract}

Contemporary economic globalization as a highly dynamic process has seen substantial changes in its organization, governance, geographies and impacts. These global shifts can be characterized by - among other aspects - increased functional and geographical fragmentation of production processes, various waves of outsourcing and off-shoring, changing geographies of production and consumption and associated labour market dynamics. At the same time, nation states and regional economic blocs aim at increasing macro-regional and global integration through bilateral and multilateral trade and investment negotiations, predicated on transformations in transportation and logistics technologies that enable the functioning of complex global production networks (GPNs) and link regional, national and supra-national economies. This paper aims to assess the consequences of what has been termed a 'logistics revolution' for economic and social upgrading in global logistics and client sectors. It starts by charting the existing research base and exploring the structure and dynamics of the global logistics industry, before addressing the potential of and obstacles to economic and social upgrading. The analysis highlights the often-neglected importance of logistics as a global industry: a major employer and value generator in its own right, with its own evolving GPNs. It demonstrates the increasingly diverse structure of logistics operations and labour markets, creating opportunities for upgrading through innovation and new technologies, but at the same time it shows the continued prevalence of 'low-road' logistics labour markets and workers often struggling to secure labour rights, decent wages and improved working conditions. These issues are illustrated and discussed for both the global logistics industry itself and the logistics activities in client sectors such as horticulture, apparel and mobile communications. The paper concludes with reflections on the contingent and variegated outcomes of logistics development and avenues for future research.

Keywords: Global production networks, logistics industry, value chain fragmentation, outsourcing, economic upgrading, social upgrading, horticulture, apparel industry, mobile communications

\section{Authors}

Neil M. Coe is Professor and Head of Department in the Department of Geography, National University of Singapore.

Martin Hess is Senior Lecturer in the Department of Geography, School of Environment, Education and Development, University of Manchester, UK.

\section{Acknowledgements}

This paper is a revised version of an earlier scoping study for the Capturing the Gains network. The authors thank Fritz Meyer for comments and suggestions, and Ross Jones for his research assistance.

This document is an output from a project funded by the UK Department for International Development (DFID), the Sustainable Consumption Institute (SCI), the Chronic Poverty Research Centre (CPRC) and the Economic and Social Research Council (ESRC). However, the views expressed and information contained in it are not necessarily those of or endorsed by the funding organizations, which can accept no responsibility for such views or information or for any reliance placed on them. 


\section{Abbreviations}

$\begin{array}{ll}\text { 1PL } & \text { First-Party Logistics Provider } \\ \text { 2PL } & \text { Second-Party Logistics Provider } \\ \text { 3G } & \text { Third Generation Mobile Technology } \\ \text { 3PL } & \text { Third-Party Logistics Provider } \\ \text { 4PL } & \text { Fourth-Party Logistics Provider } \\ \text { CPRC } & \text { Chronic Poverty Research Centre } \\ \text { CSIR } & \text { Council for Scientific and Industrial Research } \\ \text { CSR } & \text { Corporate Social Responsibility } \\ \text { CtG } & \text { Capturing the Gains } \\ \text { DC } & \text { Distribution Centre } \\ \text { DFID } & \text { Department for International Development } \\ \text { ESRC } & \text { Economic and Social Research Council } \\ \text { EDI } & \text { Electronic Data Interchange } \\ \text { EU } & \text { European Union } \\ \text { FDI } & \text { Foreign Direct Investment } \\ \text { GIS } & \text { Geographical Information System } \\ \text { GPN } & \text { Global Production Network } \\ \text { GPS } & \text { Global Positioning System } \\ \text { I2M } & \text { Inbound to Manufacturing } \\ \text { ILO } & \text { International Labour Organization } \\ \text { IMO } & \text { International Maritime Organization } \\ \text { IT } & \text { Information Technology } \\ \text { ITF } & \text { International Transport Workers Federation } \\ \text { ITU } & \text { International Telecommunications Union } \\ \text { LEI } & \text { Agricultural Economics Research Institute, Wageningen } \\ \text { LPI } & \text { Logistics Performance Index } \\ \text { LSR } & \text { Logistics Social Responsibility } \\ \text { LTL } & \text { Less than Truckload } \\ \text { MFA } & \text { Multi-Fiber Arrangement } \\ \text { NAFTA } & \text { North American Free Trade Agreement } \\ \text { NGO } & \text { Non-Governmental Organization } \\ \text { OEM } & \text { Original Equipment Manufacturer } \\ \text { RFID } & \text { Radio Frequency Identification Device } \\ \text { SCI } & \text { Sustainable Consumption Institute } \\ \text { SCM } & \text { Supply Chain Management } \\ \text { UK } & \text { United Kingdom } \\ \text { UN } & \text { United Nations } \\ \text { UNCTAD } & \text { UN Conference on Trade and Development } \\ \text { US } & \text { United States } \\ \text { WTO } & \text { World Trade Organization } \\ & \end{array}$




\section{Introduction: logistics and global production networks}

As economic globalization has deepened, the ways in which the global economy is organized have also changed substantially. Considerable shifts in the geographical location of production and consumption have been accompanied by new waves of outsourcing and offshoring, resulting in ever more complicated and changeable intra- and inter-firm global divisions of labour. While recent research has shed light on many of these issues by analysing the development and transformation of global production networks (GPNs) (for an overview see Coe et al. 2008), much less is known about the changing nature of the logistics industry in linking global production and consumption networks and organizing the spaces of material and informational flows that constitute the global economy. As an area of economic activity, logistics are now worth an estimated US\$3.6 trillion a year - and are predicted to reach US\$3.9 trillion by 2013 - a global market split fairly evenly between the Asia-Pacific (42 percent), Europe, the Middle East and Africa (30 percent) and the Americas (28 percent) (Rushton and Walker 2007). Logistics costs account for, on average, 10-15 percent of the final cost of finished products in the developed world, including transport costs (7-9 percent), warehousing costs (1-2 percent) and inventory holdings (3-5 percent). In the developing world, various forms of inefficiency mean the figure is more often in the range of 15-25 percent (Ojala et al. 2008: 443).

It is increasingly recognized that logistics services have become ever more important in contemporary production systems, owing to a range of intersecting dynamics (Dicken 2007: 410):

- The rise of new production methods involving increased flexibility;

- The increased use of just-in-time procurement and delivery systems;

- The increased geographical extent and complexity of production networks;

- The changing nature of relationships between customers and suppliers;

- The growing significance of commercial capital and retailer power;

- The growing complexity of consumer tastes and preferences.

As Aoyama et al. (2006: 331) describe, 'logistics firms operate with considerable specialized knowledge on the movement of goods, the use of information, and the organization of supply chains, all of which are particularly complex in the case of international shipments. The logistics industry also plays a pivotal role in the contemporary global economy by enabling cross-border coordination of production and making possible the seamless flow of commodities globally.' For Hall et al. (2006), the seemingly vanishing boundaries between supply, manufacturing and distribution activities are creating new power configurations within GPNs that go way beyond simple buyer- and supplier-driven dichotomies. Accordingly, they ask (p.1405, emphasis in the original), 'will logistics and freight distribution continue to be the servant of the production sector, whose performance is more or less derived by the particular demand of manufacturing for timely supply and delivery of resources and components, or is it becoming integrated, or "structural" [...] ? How might logistics concerns change global production networks into globally integrated production and distribution networks and which actors will play the major role in this context?'

It is analytically useful at this stage to make a distinction between logistics and supply chain management (see Christopher 2005; Rushton and Walker 2007):

- Logistics refers to the process of planning, implementing and managing the movement and storage of raw materials, components, finished goods and associated knowledge from the point of origin to the point of consumption. Logistics are thus an integral part of any GPN.

- Supply chain management (SCM) is a broader concept, which refers to the integrated management of all parts of a supply network from originating suppliers to end customers. It 
is therefore about the harmonization and standardization of supply chain practices across firms within a production network and, as such, connects directly to wider debates about power relations and governance regimes within GPNs.

As this paper demonstrates, a crucial trend has been for independent or third-party logistics providers to expand their operations from logistics into the broader domain of SCM. Indeed, this is the defining characteristic of what Bonacich and Wilson (2008: 3) term the ongoing logistics revolution, namely, the expansion of the term logistics to 'refer to the management of the entire supply chain, encompassing design and ordering, production, transportation and warehousing, sales, redesign and reordering. This entire cycle of production and distribution is now viewed as a single integrated unit that requires its own specialists for analysis and implementation.'

The key driver of growth in the independent logistics industry is the increased outsourcing of such services. In the abstract, firms may choose to position themselves at any point on an outsourcing continuum (Figure 1). At one extreme is the situation of total internal asset management, whereby a company keeps the entire logistics operation in-house - encompassing management, workers, systems, buildings and transport - and does not outsource anything. At the opposite end, a firm may pursue total external asset management, wherein the company outsources all of its logistics operations and undertakes no capital investment, asset management or workforce management (Rushton and Walker 2007). As Figure 1 demonstrates, however, there is a wide range of intermediate positions offering varying combinations of internal and external provision. In real terms, the two extreme positions are quite rare, with most large firms seeking to strike a balance of internal and external provision for strategic reasons. Importantly, however, by far the dominant trend is for increased outsourcing. It was estimated in the mid-2000s that only 5 percent of the global logistics industry was outsourced (Ojala et al. 2008). This figure, however, varies significantly from market to market, ranging from 2 percent in China up to 40 percent in the UK in the mid-2000s, with the figures for France, Germany, the US and Europe as a whole being 22, 28, 19 and 25 percent, respectively. In dynamic terms, however, the third-party logistics market is growing rapidly in most territories: in China, for example, the outsourced logistics market was estimated to be growing at 30 percent per year in the late 2000s (Rushton and Walker 2007).

\section{Figure 1: The logistics outsourcing continuum}

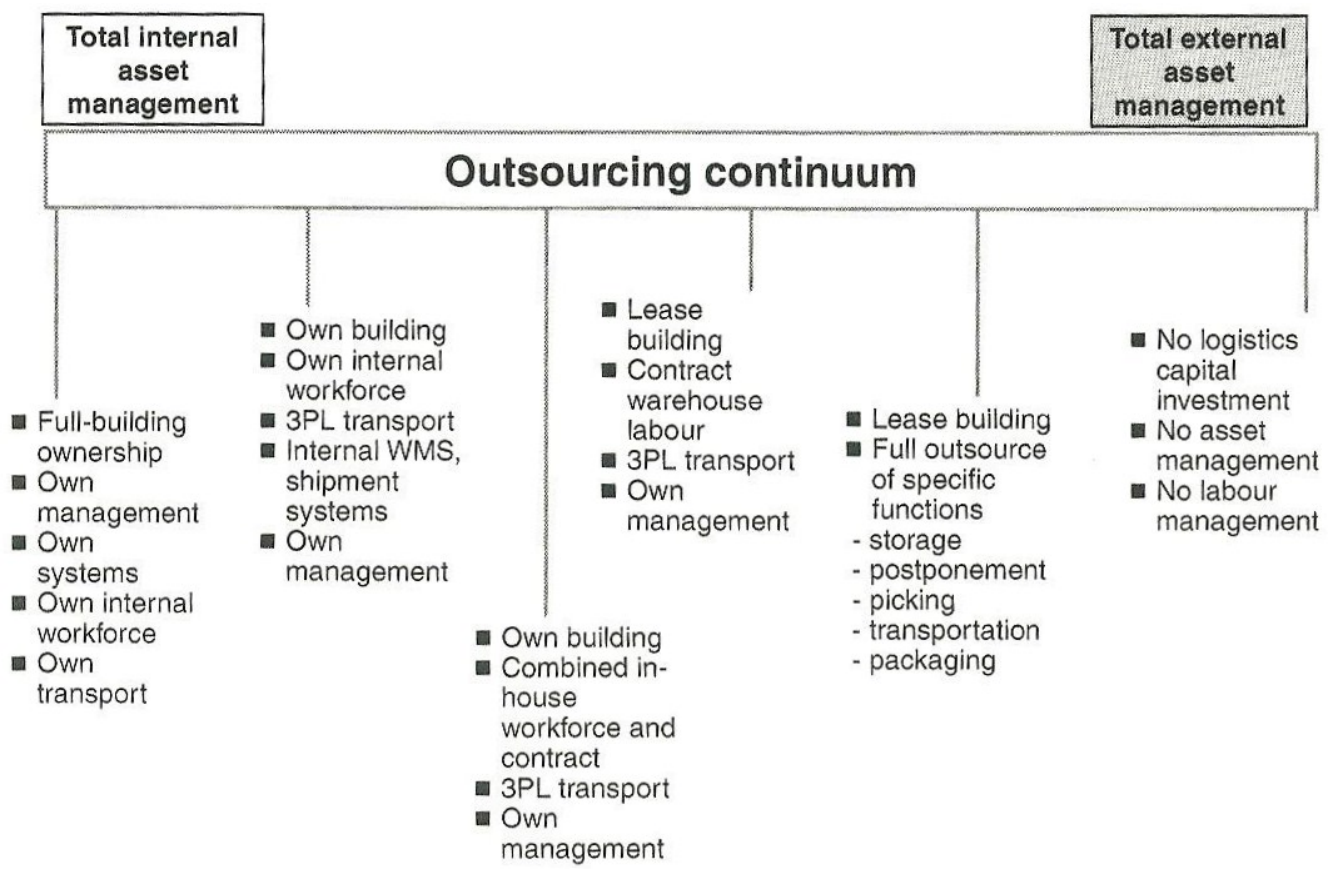

Source: Rushton and Walker (2007), Figure 3.3. 


\section{Characterizing the existing research base}

The vast majority of the existing literature on logistics follows the business/management studies tradition and is to be found in SCM and the heavily policy-oriented field of transportation studies. The past 10-15 years have seen the publication of a wide range of overview texts in this vein, including most notably Chopra and Meindl (2009), Christopher (2005), Dornier et al. (1998), Rushton and Walker (2007), Sheffi (2012), Skjøtt-Larsen et al. (2007), Voortman (2004), Waters (2010) and Wood et al. (2002). The field is also characterized by a broad range of some 20-30 journals aimed at both academics and practitioners. This literature has contributed a great deal to our understanding of the logistics industries and their increasingly strategic contributions to processes of SCM, and several of these insights inform the remainder of this paper. However, reflecting its disciplinary roots, such work has tended to focus on firm and inter-firm issues concerning efficiency, profitability and competitiveness. As such, it has paid less attention to the following aspects:

- How the growing significance of logistics providers is transforming the power relations and governance regimes in the wider GPNs in which they are embedded;

- Relatedly, how the growing significance of logistics providers is transforming patterns of value creation, enhancement and capture in the wider GPNs in which they are embedded;

- How the nature of logistics provision is shaped by the institutional and political context at a variety of spatial scales from the local to the macro-regional;

- The regional and national developmental implications of the expansion of logistics provision in different contexts;

- How firms and/or regions can upgrade their logistics industries in dynamic terms and, in turn, how logistical improvements may contribute to upgrading processes in client sectors;

- Labour and working conditions within the industry, the potential, if any, for social upgrading in the logistics industries and, again, how they may also contribute to processes of social upgrading in client sectors.

Logistics research of a more critical social science bent, however, is much thinner on the ground. Scholars in economic geography and development studies, for example, have thus far paid little attention to the kinds of questions listed above. This lacuna can be explained by both intellectual and real world trends. Hall et al. (2006), for example, contrast the strong empirical and positivist tradition of transport geography (for overviews, see Knowles 2009; O'Connor 2009) with an economic geography that is arguably much more theoretical, abstract and interpretative. In North America, many transport geographers are aligned with transportation studies - a well-funded and policy-oriented field of endeavour. In empirical terms, the falling relative cost of transport in recent decades has led many economic geographers - and indeed social scientists more generally - to take transportation and mobility as a given in the contemporary global economy. 'Logistics functions have often been viewed as tangential, auxiliary support services to production processes, providing rather simple and labour-intensive transportation and warehousing services' and thereby contributing little value-added to GPNs (Aoyama et al. 2006: 331). Hence, a situation has developed whereby, although 'economic and transport geographers generally accept the intuitive notion that economic and transport geographies (or agglomerations, nodes and networks) are mutually constituted, each sub-discipline has sought to explain only one part of the whole' (Hall et al. 2006: 1403). As Aoyama et al. (2006: 331) note, 'few studies exist to date that analyze the logistics industry using the knowledge, tools, and expertise that have been developed in economic geography'. The relatively recent emergence of an independent logistics industry may be another factor explaining the paucity of research, with the otherwise burgeoning literature on economic globalization only lately beginning to pay due attention to this industry (e.g. Dicken 2007; Hesse and Rodrigue 2004). 
Today, logistics services in their various forms have not only become a major source of employment, but also have considerable implications for both economic and social upgrading in developed and developing economies. The time for sustained research into the industry and its wider implications is ripe. The remainder of this paper is accordingly driven by two contentions:

- That there is much to be learned from exploring the logistics sector - as an industry in its own right with its own economic and social upgrading dynamics - from a GPN perspective. Such work will allow us to move beyond the supply chain literature to develop an integrative perspective that takes both the firms and their institutional environments into account (e.g. Bowen and Leinbach 2006; Leinbach and Bowen 2004);

- That there is also great potential in using a GPN framework to explore the contribution of the logistics sector to processes of economic and social upgrading in client sectors. As logistics providers expand the remit and strategic importance of the services they offer, they rework the governance and value relations of other GPNs. Very little is known about the economic and social upgrading implications of these developments.

\section{The global logistics industry}

In this section, we explore the key attributes of the logistics sector as an independent industry. Understanding these characteristics and how they are changing is a necessary first step towards unpacking the economic and social upgrading possibilities both within the industry and beyond. Four areas are covered in what follows: different kinds of logistics providers and the structure of the logistics industry; technological change and innovation in logistics; the role of the state and deregulation; and corporate strategies.

\section{Structure of the logistics industry}

General arguments about the nature and growing significance of logistics need to be accompanied by recognition that logistics services are hugely variable across, time, space and GPNs, and are provided by a rich array of inter-linked corporate actors. We can develop these arguments in five stages. The first point to make is that the inherent nature of logistics systems has changed dramatically in recent decades (see Figure 2 for a stylized version). One shorthand way of describing this broad shift is from inventory-based, or 'push', logistics to replenishment-based, or 'pull', logistics (Rodrigue 2006a; 2006b). In 'traditional' arrangements of the goods flow within GPNs (top half of Figure 2), there was a storage function acting as a buffer between raw materials suppliers and manufacturers, with a similar inventory-based warehouse on the customer side. Delays were common at all stages, leading to inventory accumulation at the various storage points. In contemporary 'demand-pull' logistics systems, by contrast, many of these costly storage facilities are eliminated (bottom half of Figure 2). Reverse flows - associated with product returns and recycling - are part of the system, and warehousing is kept to a minimum, usually in the form of a distribution centre that is throughput-oriented (see Fernie and Sparks 2004 for an excellent overview of the role of retail capital in driving many of these changes). While these reduced inventory systems are generally characterized as being lean, some commentators have contrasted lean supply networks - with an emphasis on efficiency and predictability of supply of relatively standardized commodities - with the emergence of agile networks wherein the imperative is rapid response to shifts in market demand for fashion goods (Harrison et al. 1999). 
Figure 2: The changing nature of logistics requirements
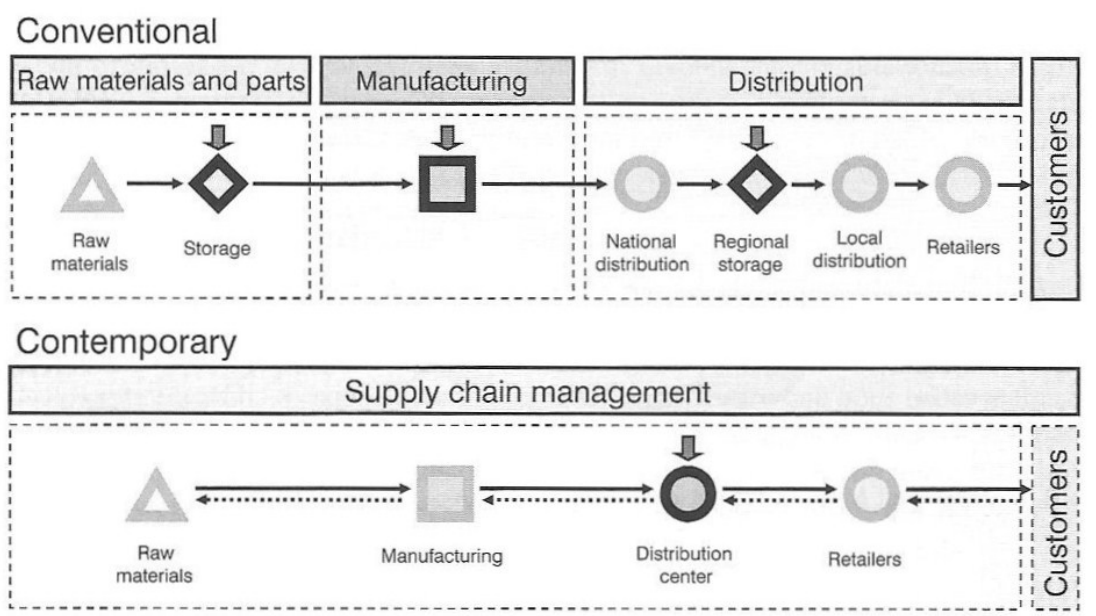

$\longrightarrow$ Material flow (delivery)

$\rightarrow \rightarrow$ Information flow (order)

I. Core component

Source: Rodrigue et al. (2006), Figure 6.7.

Concomitant with the shift in physical flows have been profound changes in the nature of knowledge flows within supply networks (see Figure 3). The traditional system was characterized by limited flow of information from the consumer to the supply network, creating time lags before producers were able to respond to shifting consumption patterns. Information flowed through orders passed sequentially from customers to suppliers, and there was limited if any visibility or transparency about either downstream or upstream processes within the supply network. The shift to what Skjøtt-Larsen et al. (2007) characterize as 'information-based supply chain flows' has seen the advent of integrated and coordinated knowledge transmission along the supply network, allowing for far more responsive distribution systems. Interestingly, these changes have also altered the nature of relationships between supply network participants and their leading logistics providers, with contracts getting longer and trust-based relations remaining important despite the use of new technologies (Aoyama and Ratick 2007). As with any simple periodization, this narrative grossly simplifies highly variegated and uneven patterns of logistics development across different firms, sectors and geographies. Nonetheless, it does helpfully distil the broad direction of change in logistics systems as SCM processes have become ever more integrated and sophisticated.

\section{Figure 3: The changing nature of knowledge flows within supply networks}

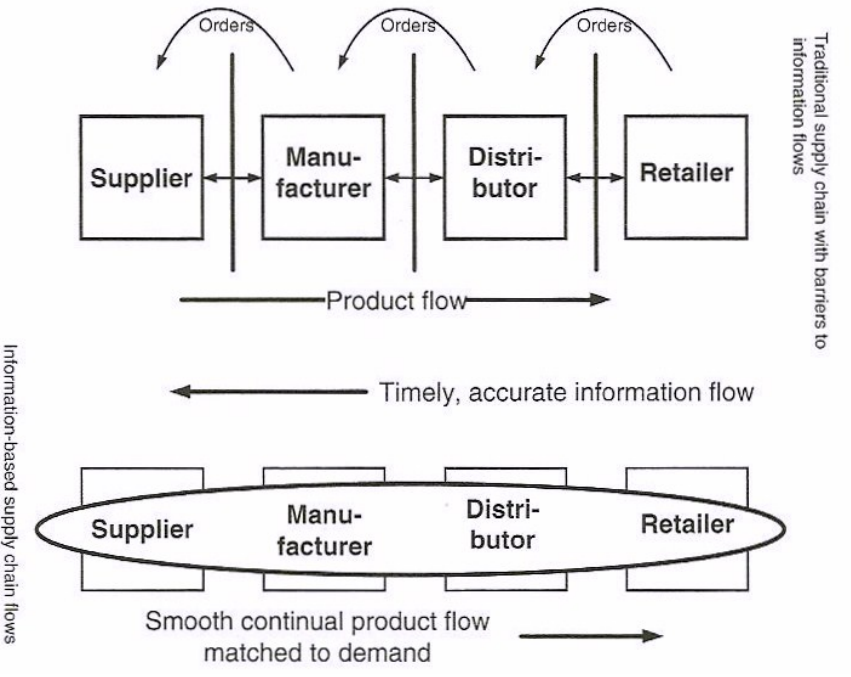

Source: Skjøtt-Larsen et al. (2007), Figure 4.3. 
The second important observation to make is that the nature of logistical requirements varies along GPNs in important ways. Rodrigue et al. (2006: 202-203), for example, compare and contrast the logistics requirements at three stages of a notional production network (see also Figure 4):

- Parts and raw materials: cost structures for parts and raw materials often lead to global sourcing, supported by international transportation by either bulk cargo (commodities) or containers (parts) in a system characterized by high volumes and low frequencies of delivery.

- Manufacturing and assembly: this stage usually concerns intermediate goods, with flows being either containerized or on pallets, with smaller volumes and high frequency of deliveries, particularly in GPNs characterized by just-in-time production systems.

- Distribution: a much more complex network of flows coordinated by distribution centres with particular territorial responsibilities, and characterized by low volume (less than truckload: $L T L)$ and high-frequency deliveries.

Building on the distinction between lean and agile networks introduced above it is also possible to think of hybrid supply network forms combining the characteristics of both types either side of key de-coupling points (e.g. a paint manufacturer using lean methods in producing base paints, and agile processes in distributing myriad different colours to retailers/consumers). Clearly, these are highly simplified representations of production networks - many real-world GPNs are far more complex and have many more actors and stages involved - but the huge variation in the kinds of services required through the system is evident. As a result, the challenges facing a logistics provider that seeks to service an entire GPN are profound: in reality, there are complex functional divisions of labour between firms that undertake different activities at different points along the GPN.

Figure 4: Different logistics requirements along the production network?

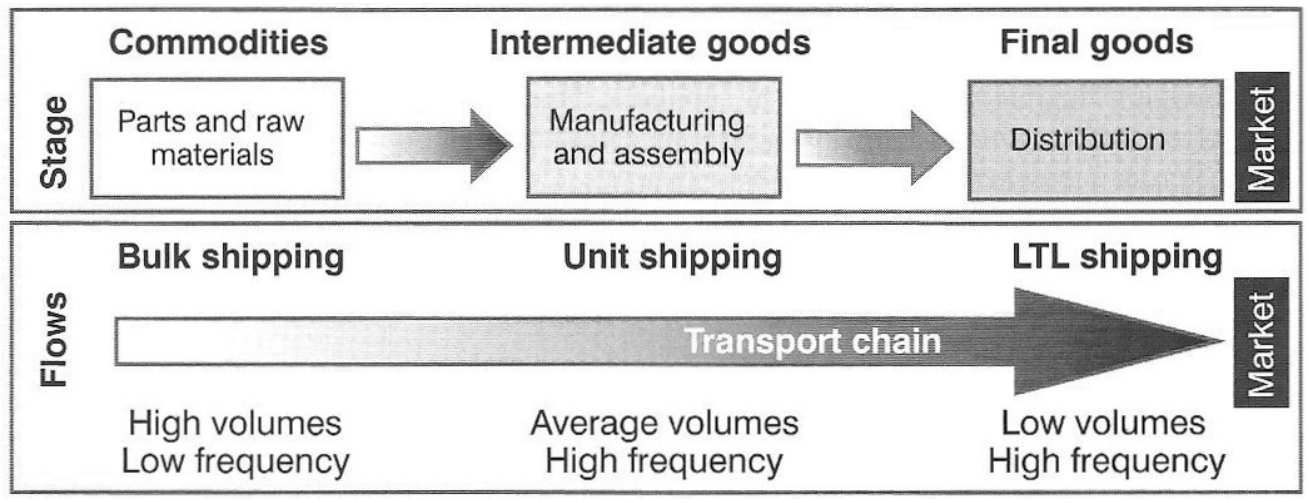

Source: Rodrigue et al. (2006), Figure 6.5.

This leads logically to the third point, namely, the wide range of providers involved in logistics provision. As Dicken (2011) notes, the various types of organization involved in logistics include transportation companies, logistics service providers, wholesalers, trading companies (such as Li \& Fung and the Japanese sogo shosha), retailers and e-tailers, and of course it should be remembered that, in global terms, the vast majority of logistics activity is still handled in-house. While transportation companies (road, rail, shipping, air freight), wholesalers and retailers play reasonably clearly delimited roles in production circuits, the categories of logistics service providers and trading companies, for example, are far more blurred, and are becoming increasingly so as such firms expand their range of activities. In short, as Aoyama and Ratick (2007: 193) describe, 'the industry is characterized by a high degree of heterogeneity in terms of the types of firms and services'. It is therefore necessary to develop typologies that provide some purchase on this 
variety. One often-used distinction is between first-, second-, third- and fourth-party logistics providers (see Figure 5):

- First-party (1PL): a fully in-house logistics function;

- Second-party (2PL), whereby a customer contracts a logistics service provider to take care of a logistics function such as transportation or warehousing;

- Third-party (3PL), whereby two (or more) supply network participants agree to outsource their integrated logistics requirements to a logistics service provider. This is the category of firms most commentators are referring to when talking about the 'logistics industry' and has seen the most dramatic growth in recent years;

- Fourth-party (4PL), in which special logistics integrators serve as market mediators and build value-adding networks connecting together supply network partners with logistics service providers. There is, however, scepticism in some quarters as to whether 4PL represents a management fad or a real-world reality. Used in a slightly broader sense, however, to denote logistics providers that are able to offer a one-stop-shop to demanding transnational clients, the term does capture the emergence of novel forms of partnership between clients firms and logistics providers that are non-asset-based and go well beyond the usual 3PL relationship.

It is worth noting this functional typology means that an individual firm can straddle several of these categories. The largest transnational logistics operators, for example, will serve different elements of their client base in a 2PL, 3PL or 4PL capacity.

Figure 5: Logistics service network structures

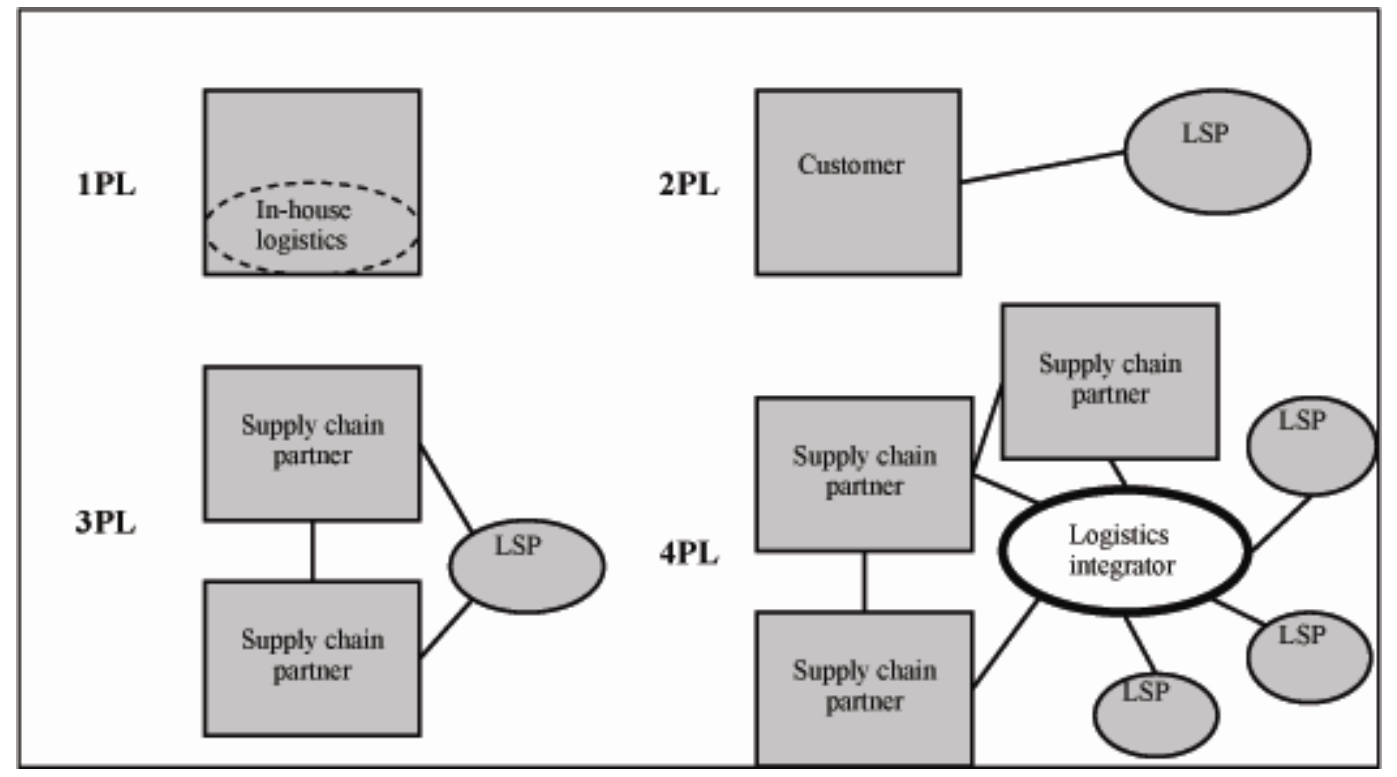

Source: Ojala et al. (2008), Box 1.

Another distinction can be made between firms that are asset-based - such as those providing transportation services over land, air or water or warehousing services - and non-asset-based operators that specialize in activities such as SCM consulting and software development, freight forwarding, selling space on ocean carriers/consolidating shipments, customs brokerage and online exchanges and brokerage. In terms of the previous typology, while most 2PL providers tend to be predominantly asset-based, 3PL providers will offer varying combinations of asset-based and non-asset-based services, whereas the competitive advantage of a 4PL provider lies primarily in non-asset-based services. 
Fourth, given the complexity of contemporary GPNs and their logistics requirements, it is apparent that, in reality, logistics needs are met by a range of different firms that are networked together or 'tiered' in particular configurations. Dicken (2007), for example, notes that the journey of one containerized shipment may involve 25 different parties and 2 or 3 different transport modes and be handled in 12-15 different physical locations. Understanding the inter-firm relationships between different kinds of logistics providers is therefore crucial to understanding economic and social upgrading dynamics. Indeed, the power and governance relationships between providers are a much under-studied area. In the example depicted in Figure 6, a 3PL or 4PL lead logistics provider is shown to coordinate a range of different providers encompassing distribution centres, parcel services, local transport, long-distance carriers and information services (e.g. software providers, supply chain consultancies). Importantly, our working definition of the logistics sector in this paper encompasses the full range of providers, from small local transport 2PL firms right up to massive transnational 3PL/4PL providers. This is important on two levels: first, to reveal the networks of inter-firm relationships that constitute the industry, as just described, and second, to allow a broad perspective on processes of economic and social upgrading in the sector to be developed.

Figure 6: The tiering of third-party logistics

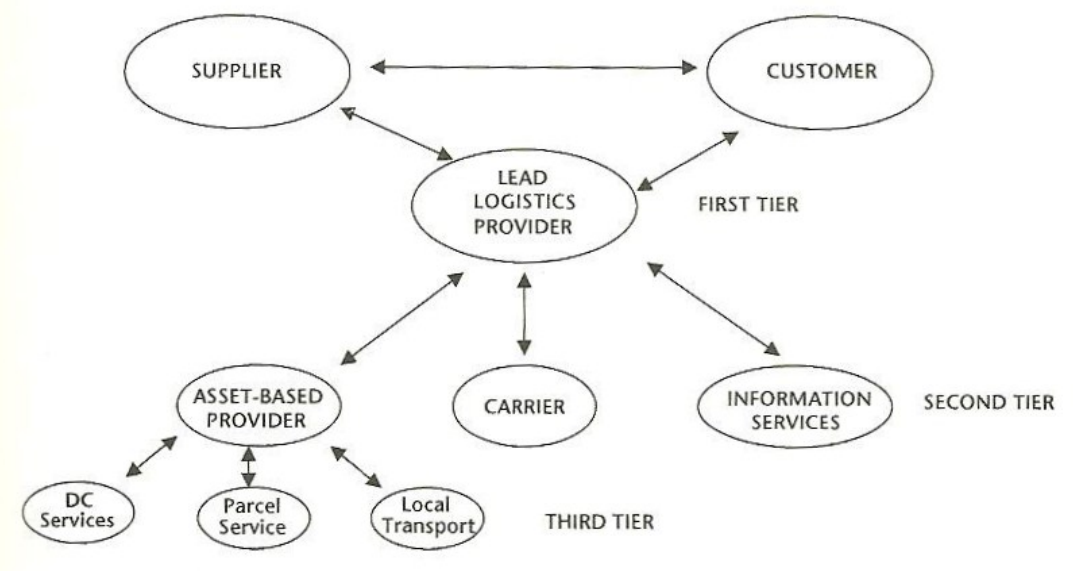

DC: distribution center

Source: Skjøtt-Larsen et al. ( 2007), Figure 9.4.

In reality, of course, the tiered network configurations (e.g. the one shown in Figure 6) are also differentiated across the various local, national and macro-regional markets they serve. It is to these geographical dimensions that we now turn as a fifth point. As by definition GPNs require transnational logistics provision, some logistics firms will have geographically specific roles (e.g. local transport providers), whereas others are explicitly concerned with linking transnationally (e.g. freight carriers). Figure 7 illustrates the typical logistics processes involved in a transnational context. Clearly, such systems are not only dealing with the physical requirements of logistics (e.g. mode transfers - sea/land, rail/lorry etc.) but also cross political boundaries and all their associated customs clearances, tariffs, duties and bureaucracy (Dicken 2007). As Aoyama and Ratick (2007: 159) describe, 'the logistics industry serves as a critical intermediary across geographic, cultural, and institutional boundaries'. From the SCM perspective, global logistics systems need to combine the virtues of both strong central control and coordination, and locally responsive customer-facing distribution systems. As Christopher (2005: 222) details:

- Strategic structuring and overall control of logistics flows must be centralized to achieve optimization of global costs.

- Control and management of customer service must be localized to the requirements of specific markets to ensure competitive advantage. 
- Trends to outsourcing of all but core competencies increase the need for global coordination of logistics capabilities.

- Global logistics information systems are key to enabling the achievement of local service needs and global cost minimization.

Such requirements create a range of crosscutting functional and geographical niches for logistics providers of varying scale and scope.

As a result, despite the rise of certain global logistics giants (to be profiled shortly), the resulting geographical divisions of labour between logistics providers should not be underplayed. As Aoyama et al. (2006: 337) describe, 'with the exception of a few emerging integrated logistics providers (such as UPS or DHL) the overwhelming majority of logistics providers possess a geographic specialty (and even the worldwide integrated firms either have branches in, or have acquired firms with, strategic geographic locational advantage). This is because transportation is primarily a local industry that requires rich, geographically-specific knowledge, even if the industry deals with international and widely geographically dispersed transactions.' They continue, 'the presence of a paradox in the industry: although the logistics industry serves an integral function in the globalization of production, it also remains one of the most localized and embedded industries of all' (p.338). Hence the need to conceptualize the interactions between global and local freight distribution systems is paramount, and the continuing strong 'local' component of logistics provision offers another reason for studying the sector through the lens of economic and social upgrading.

\section{Figure 7: Transnational logistics}

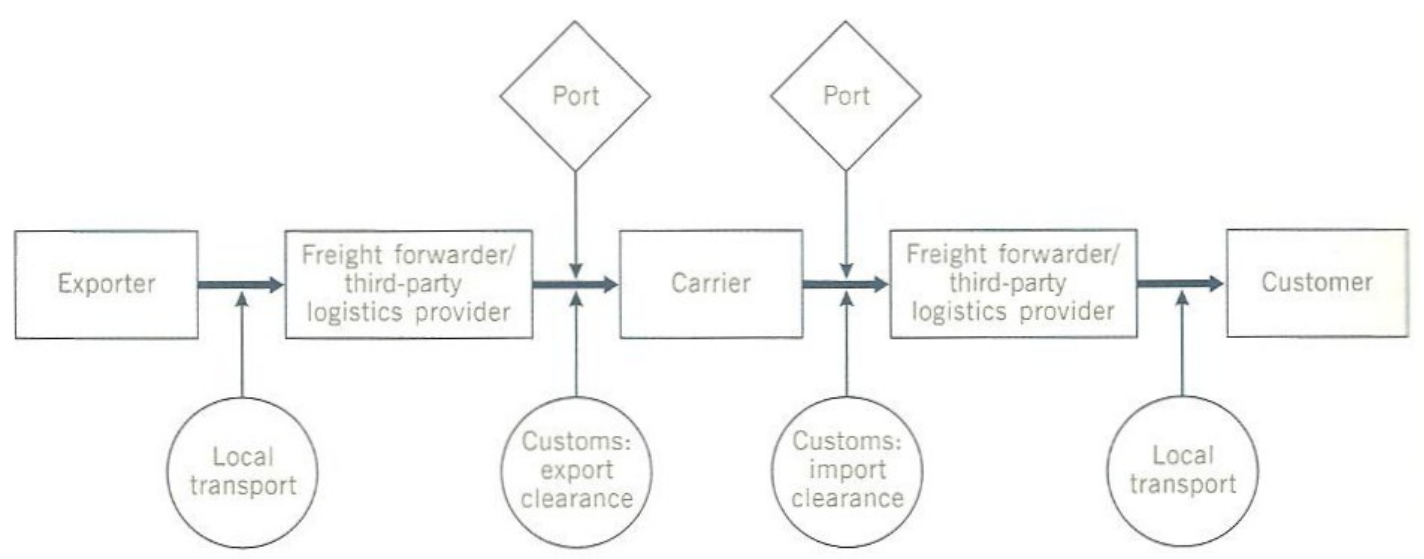

Source: Dicken (2007), Figure 14.2.

\section{Technological innovation and the logistics industry}

The nature of logistics has been profoundly transformed by the great advances in the time-space shrinking transport and communication technologies that have underpinned economic globalization more broadly (Dicken 2007). Logistics have also been transformed, however, by shifts in process technologies towards more flexible and customized production systems that place different requirements in logistics providers. In particular, the logistics industry is shaped by the need for speed, flexibility and reliability of the services it provides (Dicken 2011). Technological developments have underpinned vast improvements in all three aspects. As noted above, the broad shift has been from systems based on large stockpiles of components and products and infrequent deliveries to lean distribution systems based on the flexible, just-in-time delivery of smaller volumes of goods. 
These lean distribution systems are underpinned by technological advances in six interrelated areas (adapted from Dicken 2007: 415-416; Rodrigue et al. 2006: 208-209):

- Transportation modes: although there has been limited technological change in transport modes in recent decades, the advent of a standardized system of containerization and transhipment by the 1970s underpins the global web of intra- and inter-firm trade (Levinson 2006). As Bonacich and Wilson (2008: 50-51) recount, 'it seems safe to say that containerization was a prerequisite to global production and that, without it, globalization would have been immensely slowed down. Containerization allowed a vast increase in the speed with which cargo could be moved from one corner of the earth to another. It also greatly reduced the cost of ocean transportation, making it more cost-effective to produce at ever-greater distances from the market.' There have been more recent developments in the field, including the 'doublestacking' of containers by rail and the development of everlarger container ships in the pursuit of economies of scale. For more, see Fowler (2006), Hesse and Rodrigue (2004), Notteboom and Rodrigue (2008) and Rodrigue (2008).

- Transportation terminals: significant technological changes have seen new terminals constructed that can operate at extremely high levels of turnover. Better handling facilities have led to significant improvements in throughput, and container ports have become absolutely critical nodes in the global logistics system. Port facilities are also increasingly supported by inland terminals connected by high-capacity corridors. For more, see Almotairi and Lumsden (2009), Bichou and Gray (2004), Goetz and Rodrigue (1999), Hesse (2008), Stopford (2009), Wang and Olivier (2006) and Wang et al. (2007).

- Distribution centres (DCs): contemporary distribution centres do not hold inventory for long and are characterized by very rapid turnover of goods. They are designed for throughput and have specialized loading and unloading bays and sorting equipment. The aggressive use of cross-docking by leading retailers, for example, allows goods to be brought in, selected, repacked and dispatched to stores with limited if any time in inventory. Some of the constituent technologies of DCs are high-speed conveyors with advanced routing and switching capabilities, reliable/accurate laser scanning and powerful software/IT systems.

- Load units: load units are the basic units of freight distribution and take the forms of pallets, swap bodies, semi-trailers and containers. While containers are the dominant load unit for long-distance transport, the growing complexity of logistics ensures that a range of units are required, and tight control is maintained through the use of bar codes and radio frequency identification devices (RFID) (Sparks and Wagner 2004). These technologies allow firms to handle high levels of product differentiation and also allow the generation of instantaneous sales information with subsequent effects on inventory management along the entire supply network. For more, see Abernathy et al. (1999).

- Electronic Data Interchange (EDI): integrated IT systems and common software platforms across the supply network allow the instantaneous and secure transmission of large quantities of data concerning sales, product specifications, orders, invoices, shipment tracking and the like (e.g. Mei and Dinwoodie 2008). Increasingly, however, the Internet has become the standardized platform through which such information is exchanged.

- E-commerce: the advent of the Internet has brought about a wider series of changes to logistics and supply network configurations that go under the broad rubric of e-commerce (for more, see Fernie and McKinnon 2004; Gereffi 2001; Kenney and Curry 2001; Leinbach 2001). Both business-business and business-consumer relationships have been reworked through new forms of the electronic marketplace. As Dicken (2007) notes, the once predicted wholesale disappearance of many supply chain intermediaries has not occurred. Instead, many existing intermediaries including logistics providers have sought new valueadding strategies and, in addition, new forms of intermediaries have emerged. As Aoyama 
et al. (2006) recount, we have seen simultaneous processes of both disintermediation through the elimination of some middlemen in global networks and re-intermediation through the rise of new types of service providers, for instance e-commerce brokers, online auction firms and the like. Likewise, the notion that physical logistics infrastructures will become less important has proved unfounded. Instead, a wide range of different approaches to fulfilling e-commerce orders has developed. What is apparent is that contemporary logistics providers need to establish a presence in both real and virtual space (see also Aoyama and Ratick 2007; Li et al. 2001).

\section{The role of the state: the regulation and deregulation of logistics}

Discussion of the state in the SCM literature is mainly noticeable by its absence - many of the leading texts mentioned earlier devote only one or two pages to the topic, at best. This is a major oversight, as state regulatory regimes - particularly through their regulation of the cross-border movement of goods and services - can create 'a major discontinuity in the geographical surface over which distribution services operate' (Dicken 2007: 420). The regulatory structures that affect the operation of the logistics industries can be seen to operate at a range of scales, most notably the international, the macro-regional and the national. While such frameworks are constantly evolving, by far the dominant trend in most contexts in the past few decades has been towards the deregulation of transportation and communication systems. However, it is important to note that the regulatory conditions affecting clients' sectors can also impinge on the logistics industry. Indeed, Bonacich and Wilson (2008) go as far as to suggest that the 'logistics revolution' has ultimately been driven by neoliberalism and a regulatory context that has allowed the significant build-up of retailer power.

Dicken (2007, drawing on Braithwaite and Drahos 2000) describes how the transport and communications sectors have been regulated through a varying mix of international and national regulations developed in negotiation between international bodies (e.g. the International Maritime Organization (IMO) or the International Telecommunications Union (ITU)), national states and leading corporations. Key issues in terms of transport pertain to security and safety, while in terms of communications technological standards are a key concern. In the two pages of their text devoted to deregulation, Rushton and Walker (2007: 236-237) note the rise of macro-regional economic unions such as the European Union (EU) and the North American Free Trade Agreement (NAFTA) and the subsequent deregulation of internal markets, which have smoothed cross-border logistics in various ways, including through transport deregulation, the harmonization of legislation, the reduction of tariff barriers, the reduction of cross-border customs requirements and various forms of tax harmonization. Liberalization of trucking between the US, Canada and Mexico, for example, was part of the NAFTA agreement, although implementation in practice has proved thorny and is still not yet fully established. In general terms, at the national level there is an inherent tension between states seeking to retain control over their national transport and communications spaces, and corporate actors seeking the most deregulated environment possible. In most contexts, however, transport and communications sectors have moved rapidly in recent decades towards greater deregulation and the privatization of state-owned companies. Importantly, there may be implications for social upgrading: Bonacich and Wilson (2008), for example, chart the generally deleterious impacts of deregulation in the US trucking and railroad industries for labour conditions.

As the brevity of this section suggests, beyond the common-sense recognition that a general deregulation of cross-border flows has facilitated the development of GPNs and associated logistical systems, there are far more questions than answers when it comes to the regulatory 
dimensions of logistics. Indeed, more broadly, the interface between logistics providers and their multi-scalar institutional environments is severely under-researched. Key questions include:

- In what ways are logistics services shaped by the regulatory and institutional formations in which they are embedded at different scales?

- How far, and in what ways, do regulatory barriers continue to present an impediment to efficient transnational logistical operations?

- How do regulations pertaining to inward foreign direct investment (FDI) shape the ability of leading transnationals to invest in particular territories? What are the associated implications for processes of economic upgrading?

- What have been the implications of the general landscape of deregulation for processes of social upgrading in the logistics industry in different territories?

\section{Corporate strategies in the logistics industry}

Logistics firms have responded to the various market, technological and regulatory conditions described above in different ways. Some have sought to become comprehensive logistics providers, whereas others have remained focused on a narrower range of functions. Some have kept a relatively tight geographical focus within a particular region, country or macro-region; others have sought to expand their geographical remit either within a country, within a given macro-region (e.g. the EU, North America) or at a more avowedly global scale. A key mechanism for both functional and geographical expansion has been merger and acquisition activity, as seen, for example, in the well publicized acquisitions of Nedlloyd by Maersk (2005), Tibbett and Britton by Exel (2004) and, in turn, Exel by Deutsche Post World Net (2005) - Deutsche Post had previously acquired DHL (2003) - among many others (for more examples see Rushton and Walker 2007). Overall, it is clear the three overlapping processes of globalization, diversification and consolidation are pivotal among the leading 3PL providers, although detailed studies of the organizational and growth dynamics of these firms are scarce (e.g. Erker 2008).

The net result of these processes at the global scale has been the emergence of a cadre of large, transnational players (see Coe 2013). In terms of scope, these leading providers straddle both developed and developing markets and coordinate huge and complex global operations, with everincreasing networks in the Global South. Looking in more detail at the different kinds of firms that are developing within the logistics sector, Berglund et al. (1999) identify three types of players in the third-party logistics market in addition to traditional transport and forwarding companies (see Figure 8). First, and dating to the 1980s, asset-based logistics providers have developed from originally being operators of service assets such as trucks, airplanes and warehouses. For example, a transport company may offer DCs and information services to clients, or a DC may offer inventory management and order administration services in addition to basic warehousing. Examples of firms that have developed through this route include Geodis, DB Schenker and Penske. Second, and dating to the early 1990s, network logistics providers such as DHL, FedEx, UPS and TNT have developed from courier and express parcel companies. They have built up global transportation and communication networks in order to be able to deliver express shipments quickly and reliably, and have developed supplementary services such as electronic proof of delivery and track-and-trace options. These firms are increasingly moving into high-margin electronics, spare parts and fashion segments in direct competition with asset-based providers. Third, skills-based logistics providers (or 4PL firms) started to emerge in the late 1990s and seek to provide consultancy and financial services, IT and management skills to their clients. They may 
emerge from the other categories of firms and/or use them as subcontractors. An example would be Agility, now based in Kuwait after a series of acquisitions in recent years.

Figure 8 also provides a useful grid for conceptualizing the different diversification strategies individual firms may pursue. On the one hand, they may seek to enhance the range of asset-based services they provide, developing basic transport and warehousing services into more sophisticated SCM and DC operations. On the other hand, they may seek to develop the level of non-asset-based management services they offer.

\section{Figure 8: A typology of logistics services}

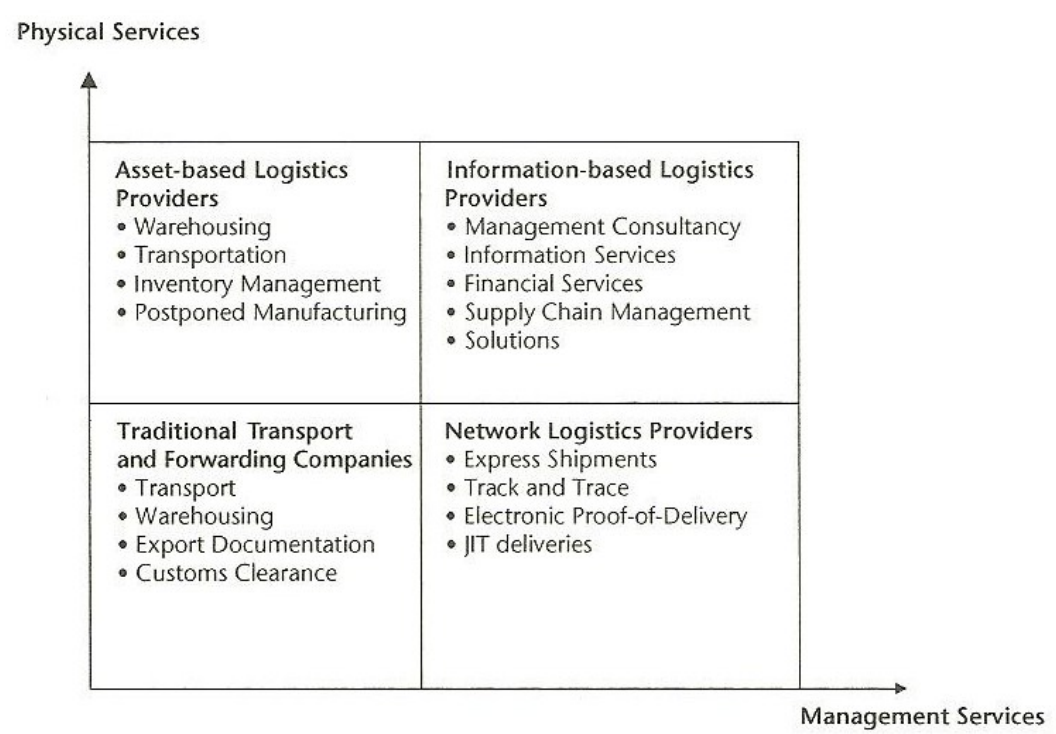

Source: Skjøtt-Larsen et al. (2007), Figure 9.3.

As a result of these ongoing diversification processes - and although the empirical evidence is somewhat patchy and anecdotal - it is clear that the range of services offered by some providers now goes well beyond those offered by traditional 3PL firms (Rushton and Walker 2007: 8-9), including:

- Manufacturing support: undertaking or supporting sourcing, managing procurement, completing light manufacturing and assembly activities;

- Origin management: managing vendors, purchase orders, in-country collections, order consolidation;

- Freight management: managing and coordinating global freight movements across all major modes of transport;

- Destination management: managing downstream operations, port to DC delivery, deconsolidation, customs brokerage, demurrage, quality checking;

- Contract distribution: storage and delivery, inventory management, DC management, preretailing (labelling etc.), reverse logistics, retail delivery, home delivery.

More specific growth areas include (Rushton and Walker 2007: 42-44):

- Transnational supply chain coordination: the integration of contract logistics activities at both source and destination into end-to-end supply chain solutions;

- Reverse logistics: handling the inherently complex and inefficient processes of good returns from customers. Estimated to be a global market worth US\$35 billion in the mid-2000s;

- Packaging: by outsourcing packaging, enables client firms to gain efficiencies by decoupling product manufacture from packaging for specific markets (and also customized marketing initiatives and product combinations); 
- Service parts logistics: found particularly in high-tech sectors, an involving ensuring postsales high-value or critical parts reach a spatially extensive customer base quickly and efficiently;

- Inbound to manufacturing (I2M): the SCM of the inbound flow of materials from suppliers to the point of production.

Having offered a broad overview of the changing market and organizational, technological and regulatory characteristics in this section, in the next two sections we look in more detail at economic and social upgrading within the logistics industry.

\section{Logistics and economic upgrading}

The discussion so far has shown that logistics services are much more than a merely tangential support activity that manufacturers and retailers have to employ. And yet, little research has been conducted so far on the implications of the logistics industry itself for economic upgrading in GPNs, as evident in the relative lack of literature on this topic. More readily available are surveys and studies that provide an aggregate picture of logistics at the level of the nation state. But these do not reveal that much about the upgrading potential within and through logistics companies, whether domestic or foreign. We briefly examine the example of the Logistics Performance Index (LPI), before turning to logistics networks and the functional, product, process and chain upgrading of service providers in this industry.

\section{The Logistics Performance Index}

For a number of years now, the World Bank has produced the annual LPI, covering 150 countries and ranking them in terms of their logistics, infrastructure and trade facilitation performance (see Arvis et al. 2012; see also Appendices 1 and 2). The LPI is an 'interactive benchmarking tool' created to help countries identify the challenges and opportunities they face in their performance on trade logistics and what they can do to improve their performance, and allows for comparisons across 150 countries. Drawing on the first-hand knowledge of logistics professionals worldwide, the index provides a comprehensive picture of supply chain performance - from customs procedures, logistics costs and infrastructure quality to the ability to track and trace shipments, timeliness in reaching destination and the competence of the domestic logistics industry. It is currently built on the following six areas of performance (Arvis et al. 2012: 1):

- Efficiency of the customs clearance process;

- Quality of trade and transport-related infrastructure;

- Ease of arranging competitively priced shipments;

- Competence and quality of logistics services;

- Ability to track and trace consignments;

- Frequency with which shipments reach the consignee within the scheduled or expected time.

While certainly not unproblematic, the index and its component indicators provide a good overview and starting point for country comparisons as well as more GPN-focused analyses of logistics and economic upgrading. The literature in the field of development economics usually agrees on the importance of an efficient logistics and transport infrastructure system not only to facilitate internal and external trade but also to attract FDI in manufacturing and services. This, in turn, is said to be a prerequisite for attracting FDI in advanced logistics services while at the same time supporting the development of an indigenous 3PL sector (see Figure 9), thus creating a virtuous circle of development. Shared by a number of transnational economic development organizations like the UN Conference on Trade and Development (UNCTAD) and the World Trade Organization (WTO), 
such a view on the benefits of logistics for economic growth has, however, been criticized for its rootedness in neoliberal ideas of free trade and development (see Martin 2008). There is no doubt that transport and logistics are crucial factors for domestic- as well as foreign-invested economic activities, especially given that the division of labour within and between firms has become ever more sophisticated. But exactly how domestic manufacturing, service and logistics sectors can benefit from the influx of FDI in production and services requires further investigation (see Chandra and Jain 2009 on the case of India).

Figure 9: GPNs and the stages of logistics market development in developing countries

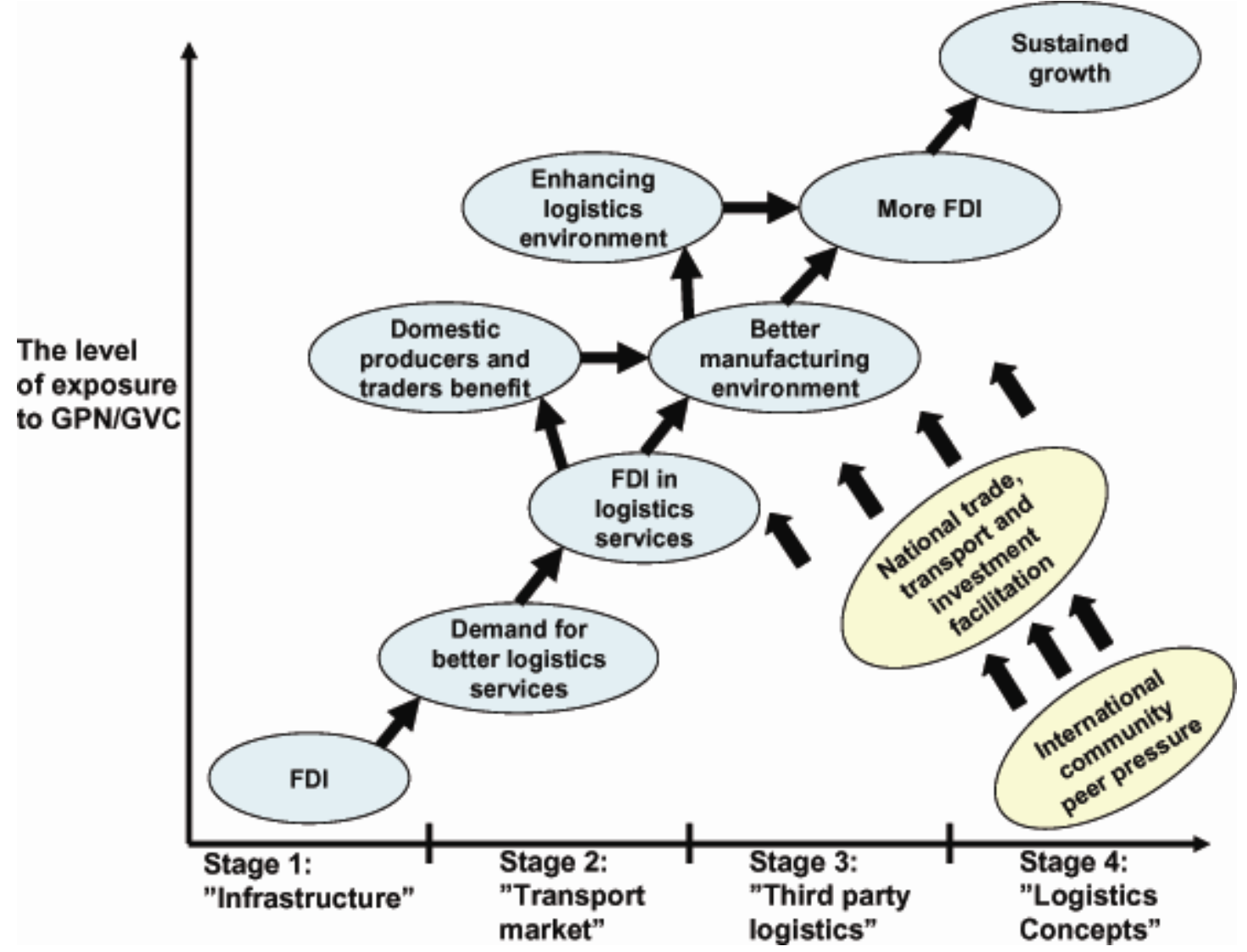

Source: Ojala et al. (2008), Figure 8.

Economic upgrading through logistics in GPNs and the regions they connect takes different forms, at the level of the region/country, the network and the firm. This corresponds with the typology of upgrading presented by Milberg and Winkler (2010). To date, the focus in the literature has been either on the aggregate national level, as with the LPI, or on the manufacturing or retailing firm, and how improved logistics and SCM can reduce inventory and cost, help enhance process efficiency and thus support productivity and the creation of value. According to a recent literature survey (Sachan and Datta 2005), more than half of the 442 publications analysed investigate the demand side at the firm level only, rather than inter-organizational aspects of logistics within GPNs and the supply side, that is, the logistics providers themselves. What is more, this kind of research is usually done in a developed economy context, most notably the US and Europe. Much less work has been carried out in the Global South, with the notable exception of China. Yet it is in the developing economies where the biggest opportunities as well as challenges for upgrading lie, which seems essential to fill the 'logistics gap' as illustrated by the LPI and other studies. The remainder of this section builds on the earlier discussion of corporate strategies in the logistics industry and follows the typology of upgrading most commonly used in GPN and global value chain research, although it is not always easy to apply in the context of the specific industry under investigation here, given the inherently service-based nature of its offering. 


\section{Process upgrading}

Advanced logistics services in GPNs are based on the increasingly sophisticated use of IT systems that ensure information flows between the various actors. Two specific technologies related to tracing the flow of goods along the value chain are of particular significance to the logistics sector: the growing use of global positioning systems (GPS) and the introduction of RFID. In developed economies, most trucks used for the road leg of the logistics chain are now equipped with GPS technology, which, combined with $3 G$ mobile communications technology, is enabling the service provider to track every movement of their fleet of vehicles (see Mintsis et al. 2004), optimize routes (the 'travelling salesman' problem) and enhance the reliability of the delivery process door-to-door. In recent years, GPS tracking technology has been combined with Geographical Information Systems (GIS) as a further step of process upgrading. As mobile communications networks expand rapidly in developing countries, there is considerable potential to update transport fleets and upgrade incumbent service providers using this technology.

RFID has now become an integral part of tracing and tracking individual consignments 'end-to-end' along the different stages of a value chain, and like GPS is now widely used for vehicle and consignment tracking. But it also offers additional benefits for GPN logistics. According to Babu (2007), there are four main reasons for the implementation of this system: cost reduction, lead-time reduction, efficient control of inbound traffic and automated management of logistics. RFID can enable 'process freedoms' and real-time visibility into supply chains (see Angeles 2005). This form of process upgrading requires logistics companies as well as their corporate clients to invest in hardware that either transmits the radio signal (the tags attached to the parcel or consignment) or reads the signal (scanner) at the various stages of transportation. This system has spread quickly in GPNs and plays an increasingly important role for producers and service providers in developing markets. For instance, Babu (2007) cites the examples of Pantaloon Retail in India, which uses RFID to track its apparel shipments at one of its warehouses, while India's largest pharmaceutical company Ranbaxy has selected logistics firm Acsis to provide the relevant RFID technology for its business with Wal-Mart. This technology also helps monitor the maintenance of quality and standards in the logistics process. Perishable products, for example, can be tagged with temperature-sensitive RFID labels which, when read out at the final destination, will have documented any breaks in the cold chain.

\section{'Product' upgrading}

Utilizing new technologies to upgrade and optimize processes, the provision of increasingly sophisticated services then becomes the major challenge that logistics companies face in terms of 'product' upgrading, a notion that does not transfer unproblematically to a service sector. As with materials and manufactured goods, however, improving and ensuring quality is a crucial factor to meet customers' demands. And given the pressures on timely delivery to make geographically dispersed GPNs work efficiently, the reliability of services provided also plays an essential role. Asset-based logistics providers have responded to these challenges by substantially improving their vehicle fleets and infrastructure on the ground. As temporary storage is continuing to be an important part of managing the flow of goods through the GPN, traditional warehouse facilities are being transformed into DCs that enable a much greater throughput and substantially reduced turnaround times between inbound and outbound docking stations, by way of introducing partly or fully automated stacking and sorting systems and optimizing the facility layout. Demand-driven order processing and order fulfilment therefore can be achieved more speedily and effectively, which may also include kitting services provided for clients from manufacturing sectors and carried out at the DC. When this is done alongside other so-called make-bulk and break-bulk activities that 
integrate or split up consignments, the DC evolves into what is known in the literature as a consolidation centre (see Higginson and Bookbinder 2005: 71).

'Product' upgrading in logistics is, however, linked to two more aspects: the provision of highly specialized services that are tailored towards meeting the requirements of specific customers and the integration and bundling of various separate services into one single package. Offering highly specialized logistics services as an option for product upgrading can be illustrated by the case of sugar cane production in Malawi, with sugar now being the second highest export earner for the country. One producer has outsourced the transport logistics to Unitrans - a 3PL based in South Africa - to manage the delivery of more than 800,000 tons of sugar cane from the customer's estate and other outgrowers to the Dwangwa Mill. 'Comprised of as many as five specially-made single-bundle trailers, each landtrain is capable of delivering up to 32.5 ton loads. The Dwangwa bundle system, though virtually unique in the African sugar industry, works well, drawing partly on round-the-clock cooperation between DSC, the out-growers and Unitrans and partly on specialised equipment such as loaders and trailers custom designed for the task' (Olsen \& Sons Advertising n.d.). Product upgrading through specialization may be the first step for incumbent logistics firms in developing countries as they can benefit from local market knowledge, and this form of upgrading - while requiring capital - is more viable as a first step to enter GPNs.

Most transnational 3PL companies now offer integrated services, as they have the resources and scale to do this effectively. One example is Hong Kong-based 3PL IDS, a member of the Li \& Fung Group. On its website, ${ }^{1}$ it reports a case of integrated SCM for an Asian multinational company that they state is just one of many instances where IDS has redefined and exploited the value chain for global companies operating in Asia. When it comes to service integration, however, the distinction between product upgrading and functional upgrading becomes very blurred, as the offering of a bundle of integrated services by $3 P L$ providers inevitably involves functional upgrading.

\section{Functional upgrading}

There are basically two ways for logistics service providers to achieve functional upgrading: they can expand their activities across the GPN by occupying more and more of the numerous material flow channels that link the various actors in the network from raw material procurement to final consumption, or they can attempt to take on value-added activities that usually have been carried out by producers and retailers themselves but are increasingly outsourced to third parties. In any case, the logistics firms perform additional functions within the value chain that enable them to retain a higher share of the value-added. In the first case, companies usually upgrade from singlemode transport service providers like trucking companies or rail freight services to multi-modal transport firms, combining various transport methods to effectively serve more than one link in the supply chain. US-based freight forwarder UPS, for instance, is able to deliver door-to-door services from the manufacturer to the retailer or final consumer through its own fleet of more than 96,000 road vehicles and 200+ aircraft. A similar picture emerges for all major international logistics providers trying to extract value at various points across globally dispersed GPNs.

The second route to functional upgrading is for companies to go beyond offering transport services and include more logistics operations. These functions include distribution inventory, warehousing, packing and packaging, order processing and communication, culminating in the provision of 3PL or 4PL SCM for entire value chains or parts thereof. Value thus is transferred to, and captured by,

\footnotetext{
${ }^{1}$ See http://www.idsgroup.com/success stories/pdf/cs Log International 1NOV.pdf
} 
increasingly integrated logistics solutions providers. Because of the volume and nature of information exchanged between 3PL and their customers, this route to functional upgrading also strengthens the position of logistics firms in GPNs - creating longer-term relationships on a more equal footing - with the potential to change the power relations and governance structures within these networks. In fact, many 3PL firms now do offer to carry out an increasing variety of functions for their clients rather than focusing on transport and services only, thus accruing even more opportunities for value creation and upgrading. While the major global players have all benefited from this, there is still considerable potential for incumbent logistics and transport firms in developing economies that needs to be unlocked.

\section{Chain upgrading}

As with product upgrading, chain upgrading is a notion that does not perfectly translate to an integrative service industry like logistics. Unlike firms in other GPNs, logistics companies have not yet moved into other sectors in the sense that they have started their own manufacturing or retailing operations. By their very nature as intermediaries between multiple actors in various GPNs, they are linked to different chains, as evidenced in the specialized service and sector divisions most transnational 3PL offer (e.g. automotive, pharmaceuticals, horticulture, electronics etc.). But in some cases, evident especially among asset-based logistics providers, there is a nascent form of cross-sectoral activity currently at the stage of light assembly, postponed manufacturing and distribution, which indicates a possible move for large 3PLs to establish a presence in production and retail value chains beyond the service functions of transport, logistics and SCM. It is too early, however, to judge the potential for chain upgrading through branching out into these areas, especially with regard to companies in the Global South.

\section{Logistics and social upgrading}

If the literature on logistics and economic upgrading is thin, then research into social upgrading in the logistics industry - and indeed labour market issues in general in the sector - is even sparser. The leading SCM/logistics texts mentioned earlier rarely, if ever, refer to workers, labour, training, skills and the like in any way. This is a massive oversight, given the huge numbers of people involved in transport and logistics in all economies. Although data are patchy, one example will suffice here: in 2011 in the UK, 1.01 million people were employed in land, water and air transport, warehousing and support activities for transportation, meaning the sector accounted for a minimum of 5 percent of total employment. ${ }^{2}$ This figure does not even include the quarter of a million people employed in postal and courier services in 2011.

This issue is compounded by the fact that the few studies that do exist on labour conditions in logistics point towards social downgrading rather than upgrading in recent times. For example, 'the logistics revolution leads to a rise in retailer power, a shift to flexible (contingent) production relations including increased offshore production, and a change in logistics to containerization, intermodalism, and JIT transportation and warehousing. These changes in turn impact labour in the form of increased contingency for workers, weakened unions, and racialization, all of which contribute to a decline in labor standards' (Bonacich and Wilson 2008: 21). Focusing on these issues reveals a dark side to the logistics sector that is simply invisible in the dominant business and management literatures on the topic. Bensman (2008) is another author who has explored the potential for technological advances to transform the logistics labour markets into a 'high-road' model of growth that would see manual labour replaced by educated labour focused on handling the large, more technically complex systems effectively and propelled by high levels of innovation

\footnotetext{
${ }^{2}$ http://www.statistics.gov.ukl, accessed 30 May 2013.
} 
and customization. His findings instead point to a widely prevalent 'low-road' labour market model creating costs both for global commerce in terms of uncertainty, delay and inventory, but also for wider society in terms of environmental externalities and strained infrastructure: 'the impact of the logistics revolution is not only that it provides employers access to far-flung networks of cheap labor, it also enables them to hire labor in ways that reduce their responsibilities, their benefit obligations, their tax liabilities, their insurance costs, and their fixed costs for equipment and so on' (Bensman 2008: 3).

Bonacich and Wilson (2008) - in one of the most comprehensive investigations into logistics labour markets currently available (based on research in Southern California) - diagnose four dimensions of the low-road growth model in contemporary logistics:

- Increased contingency: as a consequence of the advent of flexible production practices, cheaper and more readily exploitable labour forces are created through outsourcing, subcontracting and the use of temporary staffing agencies, leading to an increasingly contingent workforce. Such workers are vulnerable to detrimental management practices and are hard to organize collectively.

- Weakened unions: pressure on organized labour has been a commonplace part of the shifts in how goods are produced and transported in contemporary capitalism. Lower rates of unionization are clearly linked to increased levels of contingency and broader neoliberal economic and social policies.

- Racialization: the burden of deteriorating working conditions has fallen disproportionately on workers with few rights and least political power, both domestically and offshore. Employers actively seek out - often with the help of intermediaries such as temporary staffing agencies - racialized workforces to whom they can pay the lowest amount.

- Lowered labour standards: associated with all the above processes, declining wages and working conditions are becoming a defining characteristic of logistics labour markets.

As these points suggest, many logistics workers have been caught in a 'perfect storm' of globalization, the fragmentation of production, new logistics technologies and neoliberal deregulation of both labour markets in general and the transport industry in particular. The net result is that 'the availability of low-cost labor discourages capital investment, reduces the incentive to coordinate links in the logistics chain, reduces demand for skills and skill development and raises the burden that freight movement imposes on the public' (Bensman 2008: 15).

Summarizing - and while recognizing that the logistics workforce is both very large and highly internally differentiated - it is possible to distil some broad characteristics:

- Highly gendered: male workers predominate in the industry. For example, female workers accounted for 22 percent - a slowly growing proportion - of transport, storage and communications employment in 2005 in South Africa (CSIR 2009). Female employment is usually found in the less well-paid areas of logistics, such as sorting, packing and packaging, and tends to be casual and less secure.

- Low-skilled: while the advent of SCM and the range of sophisticated technologies described earlier in this paper have created a range of highly skilled jobs, in aggregate terms, transport and logistics are low-skilled occupations. In South Africa in 2005, for example, transport, storage and communications employment comprised 51 percent low-skill, 43 intermediate-skill and 6 percent high-skill jobs; operational, elementary and administrative positions accounted for 80 percent of the total. A related issue is the poor progression opportunities for many workers. As Bonacich and de Lara (2009: 1) describe, 'white-collar logistics jobs provide some local workers with economic advancement opportunities. Yet 
the industry's reliance on a low-wage blue-collar labor pool fails to provide a career ladder for a large portion of the logistics workforce.'

- High level of contingent working: there are high levels of short-term, contracted-out employment relations, including increasing levels of temporary staffing agency activity. 'The nature of work organisation in transport is changing greatly [...] In addition to transport workers outside formal employment relationships, the ranks of the precariously employed are swelling daily because of the increased use of outsourcing, pseudo-self-employment, casualisation and so on' (Martin 2008: 20).

- High levels of ethnic segregation: the search for low-cost labour has lead to above-average concentrations of immigrants/ethnic groups in blue-collar segments of the workforce in particular. The warehousing sector in Southern California, for example, is dominated by Latinos (Bonacich and de Lara 2009).

- Strong informal component: in developing economies in particular there are high levels of informal employment in logistics operations, especially at the upstream end of the supply network and where a large number of small enterprises or smallholders are involved. Such workers are hard to organize and can be invisible to attempts to improve working conditions.

- Decreasing unionization levels: although uneven across different components of the workforce (e.g. dockers and rail workers are still strongly unionized in certain contexts), the general trend has been for weakened union power, particularly where contingent working is strong (e.g. the warehouse/DC sector).

- Low/declining wage levels: contingent working is closely related to low and sub-living wage pay rates in many transportation segments. Bonacich and de Lara (2009), for example, found that 41 percent of blue-collar workers in Riverside and San Bernardino counties were earning less than US\$10.50/hour.

- Heavily polarized: the logistics labour market is an increasingly dualistic one, with decent work conditions and increasing skills as well as wages on the one side - primarily associated with transnational and 3PL/4PL providers - and a much larger domain of lowwage casual labour characterized by job insecurity on the other.

Beyond these broad generalizations, it is important to recognize the different intersections of the above dynamics in different parts of the workforce. For example, one can make distinctions between maritime workers, dockers/longshoremen, truck drivers and warehouse workers:

- Maritime workers: an International Labour Organization (ILO) report (2004) depicted the intensification of working practices in maritime shipping, characterized by steep hierarchies, social isolation, smaller crew sizes, lower wages and less time in port, and resulting in high levels of stress and alcoholism. The workforce is also heavily segmented by national origin - with workers coming primarily from countries such as Bangladesh, China, Estonia, India, Latvia, Pakistan and the Philippines (for more on maritime workers, see Bonacich and Wilson 2008: Chapter 7).

- Dock workers: union power in the longshore sector has been diminished in contexts such as South Korea, New Zealand and the UK (e.g. Turnbull 2000; Turnbull and Wass 2007). In other contexts, dock workers have more successfully fended off deregulation, but employee numbers continue to decline despite rising trade levels. In developing countries, such processes have often been promulgated by international agencies such as the World Bank, which has produced, for example, a Port Reform Toolkit detailing how to improve competitiveness and efficiency and reduce costs. 'However, the approach advocated in the toolkit has brought large-scale job losses and casualisation' (Martin 2008: 10), justified by 
the World Bank in terms of the extra jobs supposedly created in the hinterland by increased port efficiency (for more on dock workers, see Bonacich and Wilson 2008: Chapter 7).

- Truck drivers: contracting out and deregulation in port trucking (drayage) in the US has led to vicious competition, inhuman working hours, health and safety issues and falling wage levels, and these poor conditions are mirrored in Canada, China, India, South Africa and South Korea (Bensman 2008). According to the International Transport Workers Federation (ITF) (2006), 'in the goods transport sector, unions note the growth of informal truck operators employing workers without formal contracts, rights or benefits, including migrant workers. And there are many self-employed workers, or workers in disguised forms of employment, eking out a living by carting rubbish, carrying luggage, repairing tyres, selling petrol and so on. Women workers are found most commonly in non-standard forms of employment, such as part-time and temporary work in administration and logistics, in call centres and on cruise ships. These jobs may or may not be informal. At the informal, survivalist end of the spectrum, women are most often located in support functions such as preparing and selling food to passengers, cleaning, processing and selling fish or petrol. Informal transport workers share similar problems and have similar needs as other workers in the informal economy. Commonly they are excluded in law or practice from labour and social protection laws. They lack representation and voice and are unorganised or ineffectively organized. They have a large number of concerns, including job insecurity, low and insecure income, harassment and corruption by authorities, poor facilities, and no access to training' (for more on the conditions facing truck drivers, see Bonacich and Wilson 2008: Chapter 8).

- Warehouse and DC workers: here, the high-road solution of modern DCs sits alongside a parallel industry of more rudimentary storage, where employers often use temporary employment agencies to supply immigrants willing to work without health insurance or pension benefits (Bensman 2008). Agency workers often work alongside directly hired employees who are paid more and work longer hours (for more on warehouse and DC workers, see Bonacich and Wilson 2008: Chapter 9).

Studies on more high-skill/SCM workforce segments do not seem to exist, although clearly the labour market conditions will be very different. This suggests that large 3PL providers will have highly internally variegated labour forces ranging from software specialists to warehouse operatives and drivers.

Perhaps understandably given the above, sector-wide initiatives barely seem to have tackled the issue of social upgrading in the logistics industry. More attention is undoubtedly being paid to the sustainable aspects of transport and logistics, with an emerging body of literature focusing on 'greening' the supply chain, often under the wider umbrella of corporate social responsibility (CSR). Global logistics providers in most cases do subscribe to a code of conduct, and most will comply with the Global Compact and ILO schemes, among others, but the firm documentation on CSR puts emphasis on labour conditions and the environment in the home economies, with considerably less information about their subsidiaries and networks in the Global South. Ciliberti et al. (2008) offer a useful overview of CSR practices in the logistics industry, or what they term LSR - Logistics Social Responsibility (see also Carter and Jennings 2002). LSR can be seen to encompass six domains: environment; ethics; diversity; working conditions and human rights; safety; and philanthropy and community involvement. Ciliberti et al.'s review of the existing literature, however, found that the human rights dimension was largely concerned with analysing the labour conditions of workers in supplier companies rather than in-house. Their study of Italian firms found that economic and environmental concerns were taking precedence over issues of social upgrading in supply networks. Writing in 2008, Seuring et al. estimated that over 190 papers 
had been published on the relationship between environmental issues/sustainable development and SCM. Again, however, it is evident that social issues are downplayed in terms of environmental dimensions in particular, and discussion of labour conditions and practices within the logistics elements is non-existent (Hall and Matos 2010).

Discussing the potential for social upgrading in logistics may seem somewhat futile in the face of (i) the previous discussion and (ii) the paucity of research on logistics labour markets. However, this does suggest a significant and pressing research gap that the Capturing the Gains (CtG) programme can usefully pursue. From the perspective of developing countries, social upgrading or a switch from low-road to high-road labour markets - will necessitate coordinated action by both state and corporate actors. From the perspective of the state, careful labour market regulation is needed to prevent the erosion of wages and working conditions within highly competitive and contingent segments. Evidence suggests that higher levels of unionization may have a positive effect on wage levels, as unionized workers can earn significantly more than their non-union counterparts (Bonacich and de Lara 2009). The interconnectedness of various logistics and transport sectors also allows for the possibility of inter-union cooperation (see Bonacich 2005) at different scales: one such platform for global cooperation is the ITF, which represents 751 unions and 4.6 million workers from 154 countries. State involvement is also of paramount importance in the domain of education and skills development, and in terms of encouraging inward FDI in the logistics sector in order to bring much-needed investment and skills/knowledge. Firms of all sizes and origins need to be encouraged to pursue combinations of the modes of economic upgrading described earlier in this paper in order to try and generate associated social upgrading benefits. However, until we have a solid base of data on, and research into, logistics labour market conditions in the Global South, assessments of the impacts of such dynamics will prove virtually impossible to make.

\section{Logistics: economic and social upgrading in client sectors}

In general terms, efficient logistics contribute to added value in wider GPNs in four interrelated ways (Rodrigue et al. 2006: 206; see also Boschma and Lambooy 2004):

- Production: improved efficiency of manufacturing with appropriate shipment sizes and inventory levels. Production costs are reduced by 'streamlining' the supply network;

- Location: taking better advantage of locations to deliver expanded markets and lower distribution costs;

- Time: having goods and services available when required along the supply network with good inventory and transportation management;

- Control: derived from controlling most, if not all, stages from production to distribution, enabling better marketing and demand response and allocating distribution resources accordingly.

While all of these aspects are important for any GPN to be organized effectively and therefore enhance its overall competitiveness, there are differences in the ways the above listed factors interrelate, depending on the structure and organizational as well as geographical complexity of a specific GPN. Yet relatively little is known about the sector-specific contributions of logistics to value chain transformation and upgrading in various industries.

\section{Logistics in the horticulture sector}

Products like vegetables and cut flowers are high value crops, but get the premium prices only when they make it to the markets in Europe quickly and in good shape. For example, a rose from an Ethiopian greenhouse has a potential value of $0.10-0.35$ per stem at the Dutch auction. However, 
such prices are fetched only when the produce make it to the major flower markets without any loss of quality and value. An optimal cool chain from the farm to the export market is an essential part for the Ethiopian horticultural industry (Joosten 2007: 28).

The above quote illustrates the crucial role of logistics in value creation and economic upgrading in horticulture GPNs (see Figure 10). As the five-day flight ban in 2010 across most of European airspace - owing to a cloud of volcanic ash from Iceland - has shown, the GPNs of horticultural, perishable products are particularly vulnerable if logistics systems are interrupted. For example, the restriction on flights in April 2010, according to some estimates, cost the Kenyan cut flower industry US $\$ 2$ million a day, and thousands of people - mostly casual workers - were laid off. In Kenya, horticulture generates US\$110 million exports per year and employs an estimated 500,000 people, 75 percent of whom are women earning up to US\$30 per month (see tranformationallogistics.com). Under intensifying globalization, many developing economies have become increasingly reliant on export markets for horticultural products, which often are the single most important sector for international trade. Airfreight and a reliable cold chain (see Smith and Sparks 2004) are crucial for these GPNs to work, which in turn has attracted logistics FDI by transnational 3PL companies that usually have dedicated and industry-specific business divisions. One example can be found in the Kenyan cut flower industry: 'Farmers used to bring their products to the airport by every conceivable means, but today Kuehne + Nagel collects the flowers all over the country according to a fixed timetable with five refrigerated trucks, all of them equipped with the latest RFID technology. In Kuehne and Nagel's own cold store facility at the airport, the company's employees unload the flowers from the trucks and consolidate the shipments on airfreight pallets for the various flights' (Kuehne and Nagel 2009: 12).

In horticulture value chains, making sure that the produce is kept refrigerated all the time is imperative to all related logistics operations, from the farm to the retail outlet in the destination country. It is the only way to ensure quality, meet the standards required by international buyers and therefore enhance the value in the form of higher asking prices. As illustrated by Korsten et al. (2008: 170) the cold chain starts on the farm, immediately after harvesting, continues through the stages of temporary storage at the farm (first-in, first-out rotation) and transport to market and ends with storage at the place of final consumption. Compared with other supply chains, this system is more capital-intensive, as it requires specific technologies and infrastructure, and therefore the barriers to entry for local transport and logistics companies in developing economies are higher, especially if production and resulting transport volumes are low. An example of this is the Ghanaian pineapple sector, where transport costs are very high compared with other African countries (see LEI, n.d.). As a result, there are currently few incentives for local service providers to invest in refrigerated trucks and other cold chain facilities. The lack of high-quality cold chain logistics in turn has a negative impact on product quality, therefore reducing export opportunities, which affects the volume, speed and frequency of international transport to market, leading to a vicious circle and severely constraining upgrading opportunities as economies of scale cannot be realized. 
Figure 10: Logistics of cut flower production in Ethiopia

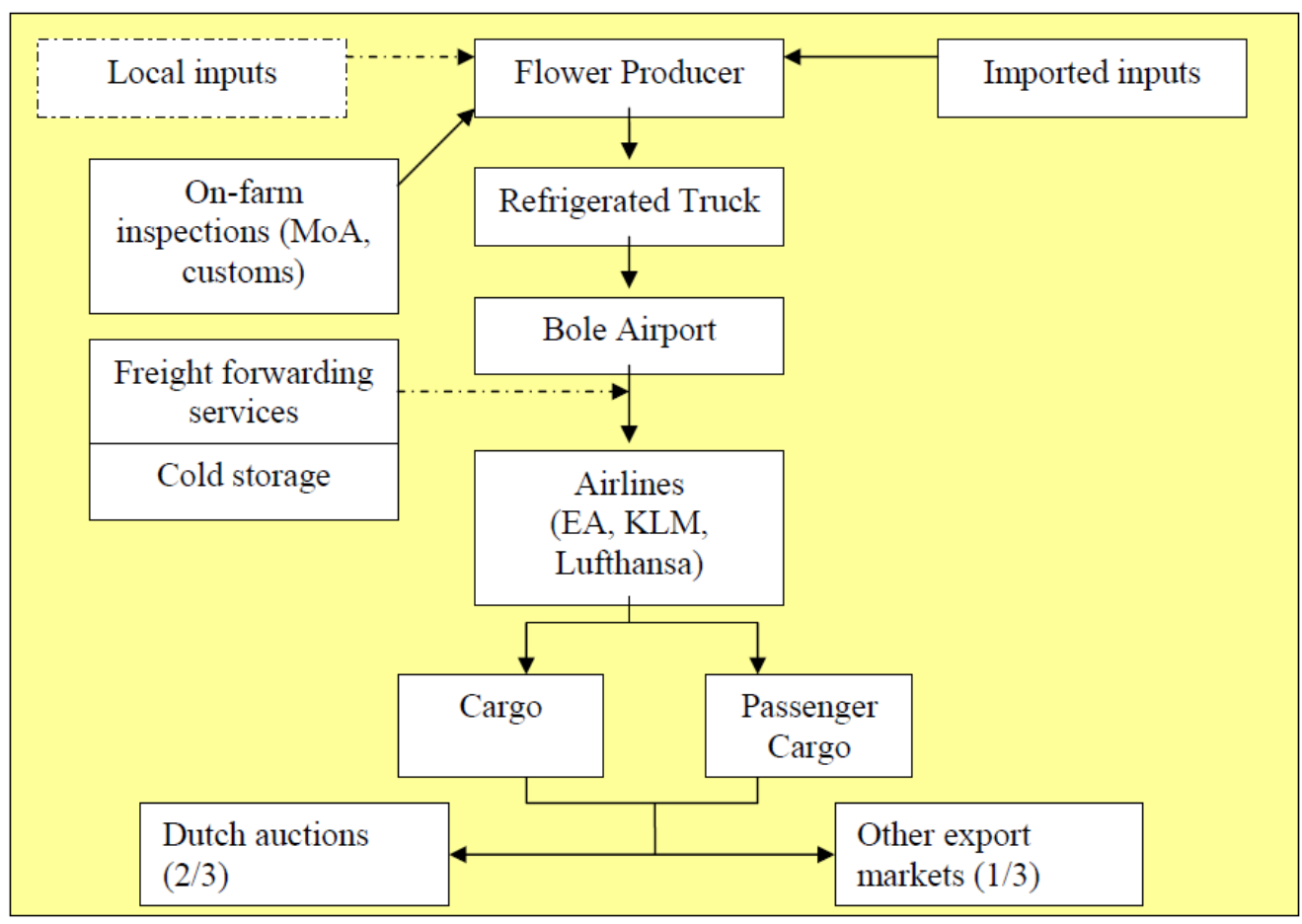

Source: Joosten (2007), 29.

The existing literature is acknowledging that deficiencies in logistics systems are among the most important obstacles to upgrading and development in horticulture GPNs (see Joosten 2007; Vagneron et al. 2009) According to one source, '[h]igh delivery costs, caused primarily by a fragmented supply chain, bad logistics, together with poor standards are hurting India's horticulture exports much more than trade barriers, according to a World Bank report' (http://www.rediff.com/money/2007/apr/19export.htm). Although the Indian horticultural industry is competitive in terms of production and labour cost, its share of world exports is disproportionally low. Producing 11 percent of the world's vegetables and 15 percent of the world's fruits, the figures for international trade are only 1.7 percent and 0.5 percent, respectively. One of the reasons apart from insufficient domestic logistics - is that international transport costs from India to export markets are 20-30 percent higher than in competitor countries. Shipping grapes from India to the Netherlands, for example, costs two and a half times more than from Chile.

To realize the potential of economic and social upgrading that can be found in the logistics activities within horticulture GPNs, it is crucial to improve and integrate logistics at all stages and by all relevant actors. The Agricultural Economics Research Institute, Wageningen (LEI) (n.d... 25) identifies and summarizes four important areas for improvement in the field of logistics:

- The generation of sufficient production volumes, especially for export markets. To achieve these, improvement and maintenance of product quality are imperative. Rising volumes in turn lead to lower transport and shipping costs;

- Stronger collaboration between large-scale, medium-sized and small-scale producers, based on long-term relationships. This can lead to a reduction of risk for each participant, faster response times and lower investment costs through resource pooling;

- Stronger collaboration between producers, which can also help simplify certification and quality control procedures, which will in turn reduce the logistics problems associated with customs and clearance procedures;

- Investment in refrigeration facilities to establish a fully integrated cold chain. 
Improved on-farm logistics operations and sufficient production/export volumes are a prerequisite for the attraction of logistics FDI and - following Joosten (2007: 29) - for the emergence of a series of domestic logistics services, such as:

- Specialized freight forwarders and clearing agents;

- Appropriate storage and warehousing facilities, including established insurance provision to ensure an effective throughput;

- Organised and centralized customs and phyto-sanitary services to facilitate the flow of goods and services at ports and airports.

\section{Logistics in the apparel sector}

The challenge of economic and social upgrading in apparel GPNs has been the focus of many academic studies to date (see Abernathy et al. 1999; 2006; Danskin et al. 2005; Gereffi 1999; Gereffi and Memedovic 2003; Schrank 2004). Like horticulture, the apparel sector is an important source of employment and export earnings in a considerable number of emerging and developing economies. It also has come under intense scrutiny from social campaigners and nongovernmental organizations (NGOs), highlighting the extremely poor working conditions found in many factories and countries. Being a labour-intensive industry in search of low-cost production locations, the geographical and organizational structures of apparel GPNs have seen substantial changes over the past few decades. Driven by large retail buyers and branded manufacturers, and recently transformed by the abolishment of trade quotas that existed under the Multi-Fiber Arrangement (MFA), the apparel and garments production process has become ever more dispersed and created what is known as triangle manufacturing or global logistics contracting (see Antonio and Rodolfo 2006; Gereffi 1999). This is a system whereby the buyer places orders with apparel manufacturers, which in turn then outsource and/or offshore production to partners in lowwage countries. These contract suppliers then ship the product directly to the buyer, completing the triangle. Coordinating the triangle manufacturing system requires sophisticated logistics operations, both inbound (the sourcing of raw materials and fabric/textiles) and outbound (shipments to buyers and customers, see Figure 11).

For producers in developing economies, the challenge to stay competitive and be able to participate successfully in apparel GPN is not just a matter of labour and production cost; also, in the fast-moving world of fashion and lean retailing practices (see Abernathy et al. 2006; Christopher et al. 2004), reducing lead times and ensuring timely deliveries has become much more important, especially in the de-regulated post-MFA era, and logistics play a major role in reducing time to market. At the upstream end, apparel manufacturers often face difficulties when searching for reliable materials and fabric suppliers, as many of them do not have the capacity to operate their own buying offices and develop appropriate inbound logistics. Producers in countries that lack their own cotton, synthetic fibre and textiles industries are particularly vulnerable and therefore at risk of losing their place in the value chain. They are also hampered by timeconsuming customs and import/export procedures for materials and finished goods. Outbound logistics, on the other hand, becomes an issue when the producer fails to meet the delivery deadlines set by the buyer. In this case, transport costs may increase dramatically as the producer will have to resort to airfreight instead of shipping consignments by sea in order to fulfil their contract. This may be less problematic for high-value fashion garments that often are airfreighted anyway, but has serious implications for lower-value garments. Apart from the much higher cost of shipping, producers also face severe overtime charges from their overseas buyers, which small and medium-sized producers in particular can ill afford. 
As buyers apply lean retail strategies and producers often lack the financial and organizational resources, logistics in the apparel sector has become an activity that is increasingly carried out through 3PL providers. One of the best-known examples is Li \& Fung Trading, the largest and most important business division of the Hong Kong-based Li \& Fung Group (see Coe et al. 2013; Dicken 2011). As a major global player, this company offers the management of the entire supply chain for global buyers such as Levi Strauss and Reebok and specializes in service provision for the apparel and garment industry. The company controls and coordinates 'front-end' operations such as design and production planning, materials sourcing and manufacturing, and the 'back-end' tasks of quality control, product testing and logistics. Although not owning any production capacity itself, Li \& Fung is able to draw on a network of more than 12,000 suppliers to meet the needs of its clients across the world. Beyond the large customers, Li \& Fung's strength also derives from its ability to match small and medium-sized Western retailers with small and medium-sized manufacturers across Asia while benefiting itself from scale economies derived from its huge buying power. In a similar vein, German logistics giant DHL has become a major player in the apparel value chain and now provides integrated logistics solutions, from material purchasing to the sampling business, to quality control of production and direct delivery to buyers and retail outlets. To achieve its aims of providing end-to-end solutions including manufacturing and supplier services, origin management, freight management, destination management and in-country logistics, DHL has begun to set up a series of Fashion and Apparel Centres of Excellence throughout the Asia-Pacific region, with four out of its current seven facilities opened over the course of 2009 in Tirupur/India, Hong Kong/China, Ho Chi Minh City/Vietnam and Karachi/Pakistan (http://www.logisticsmgmt.com/). (It also has just announced a new US\$10 million investment in a joint venture in Bangladesh, creating another centre of excellence and expanding its presence.)

In terms of economic upgrading, as the intermediaries between buyers and manufacturers, 3PL providers play an important role in technology and know-how transfer, in particular through training in and the implementation of information technologies (EDI, RFID) that enhance the visibility and traceability of orders (see Schrank 2004; also Figure 11). As the managing director of DHL Global Forwarding Bangladesh states, 'The investment in Bangladesh will go towards strengthening the joint venture, employee training, upgrading of information systems, enhancing and expanding the infrastructure and introducing a range of new services for businesses in Bangladesh' (www.commodityonline.com). 3PL - along with global buyers - therefore become major drivers for upgrading in the apparel chain as producers face what Moodley (2003) calls the challenge of ebusiness. As new technologies transform the relationships between firms and other actors like the state (e.g. through electronic systems for customs and clearance) in the apparel GPN, they also impact on social upgrading by creating new and skilled jobs in an industry that is generally considered to be a low-tech sector. 
Figure 11: Logistics in the apparel supply chain

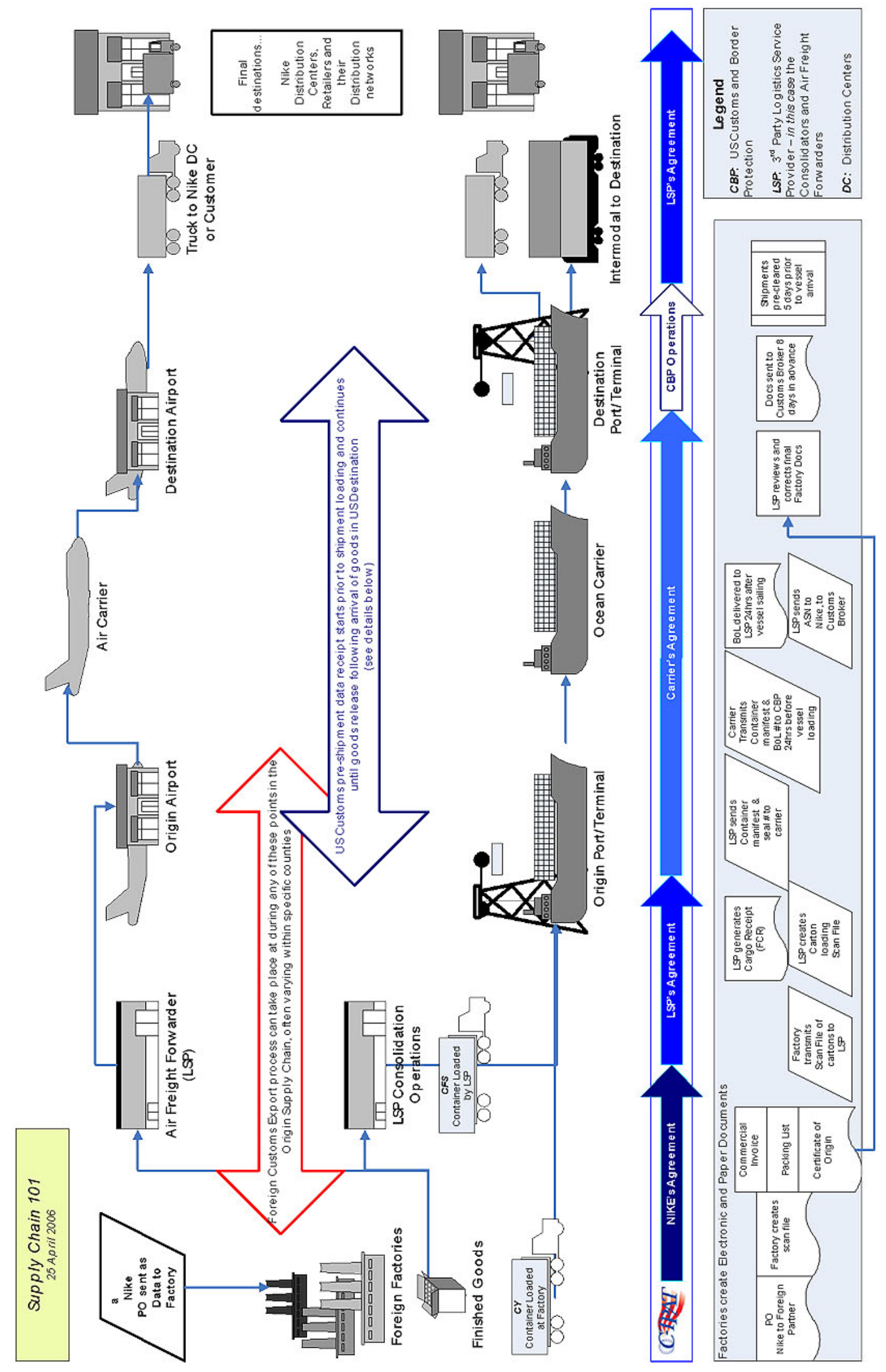

Source: www.starboardalliance.com/shippers.htm 


\section{Logistics in the mobile communications sector}

Compared with the horticulture and apparel GPNs, the mobile communications sector displays an even greater degree of organizational and technological complexity, variety and number of inputs, and combines manufacturing and service provision in a unique way (see Fransman 2002; Hess and Coe 2006). The focal firms and main drivers in mobile communications GPNs are the branded manufacturers like Nokia, Samsung or Motorola, which command a multi-tiered upstream, inbound logistics network, whereas mobile service providers like Vodafone and Singtel focus on downstream logistics operations for physical products (handsets) and voice/data services (Catalan and Kotzab 2003: 673). Figure 12 provides a representation of the mobile phone supply chain and the process links between its different elements. Highly efficient logistics systems are again imperative to ensure the functioning of the GPN, where speed is of the essence in terms of not only time-to-market of the finished product but also just-in-time delivery at more numerous and complex stages of the production and distribution process.

The electronics sector, of which the mobile communications industry now is a sizeable segment, in many ways epitomizes the new, global division of labour, as it has shifted from a Fordist model of production and organization towards a post-Fordist, time-based form of organization as well as competition (see van Egeraat and Jacobson 2005), reflecting ever-shorter product life cycles and increasingly differentiated markets. In this context, Catalan and Kotzab (2003: 674) identify nine mobile phone supply chain elements that all have implications for logistics and SCM:

- Product facility structure: number of warehouses, level of inventory, product structure and distribution structure;

- Process orientation and work flow structure: inter-firm functional or process orientation;

- Organizational structure: intra- and inter-organizational team work;

- Communication and information structure: level and frequency of information level;

- Planning and controlling: joint level of planning and joint level of using performance measures;

- Management methods: synchronization of management and workforce and level of complementary philosophies;

- Risks and rewards: degree of fairness of sharing risks and rewards among the supply chain members;

- Power and leadership: level of commitment;

- Culture and attitude: joint terminology and attitude towards cooperation;

It therefore is not surprising that mobile phone assembly is geographically highly concentrated in original equipment manufacturer (OEM)-led manufacturing clusters in order to optimize chain processes. Where such a manufacturing cluster is difficult to establish, manufacturers have been implementing a 'hubbing' system, in which suppliers not able to supply directly leave a minimum volume of products in a location close to the factory - the hub. In most cases, they consolidate around one or two hubs managed by third-party logistics providers (see van Egeraat and Jacobson 2005). These hubs in turn are linked to airport logistics parks, as air cargo services have become a crucial link in electronics GPNs. According to Leinbach and Bowen (2004: 305-306), air cargo services factor in GPNs in three discernible ways. First, their cost, capacity and reliability help define the geographical scale over which networks are realized. Second, they reflect and reinforce a GPN's geography by channelling its expansion along specific corridors. Third, since air cargo services are strongly regulated by the state, they are one of the important mechanisms through which governments continue to maintain a decisive impact on the configuration of GPNs. 
Figure 12: The mobile phone supply chain and logistics

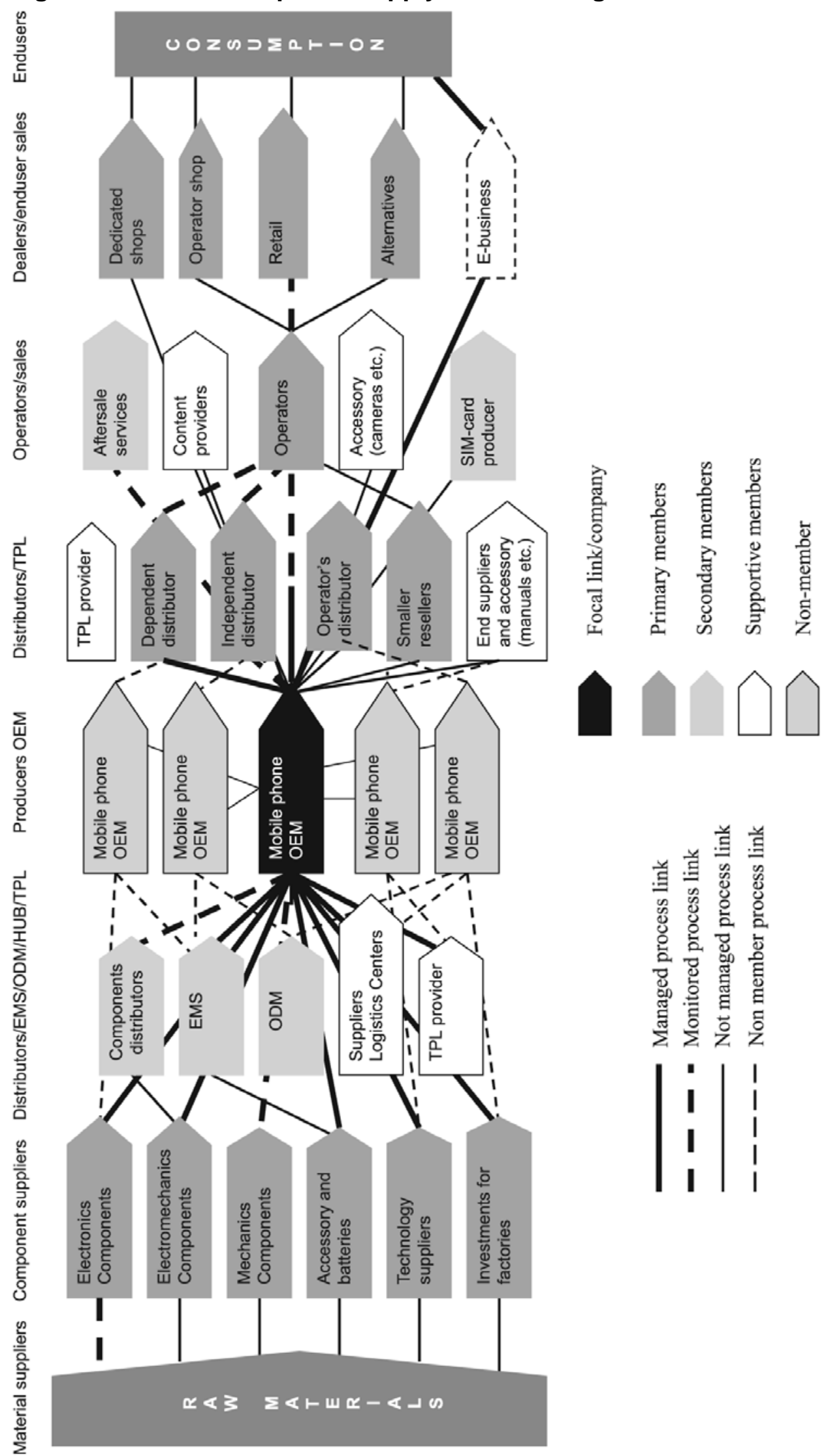

Source: Catalan and Kotzab (2003), 672.

Mobile communications have been identified as a major factor in economic and social upgrading in developing economies, through both production activities and the use of mobile services (see Lee and Gereffi 2013). From a logistics perspective, apart from the employment and skills opportunities 
the expansion of the mobile communications sector provides, there are two notable additional areas of upgrading potential: logistics provision for distribution, sales and after-sales services; and supplier relationship management at the upstream end of manufacturing value chains.

First, in contrast with the predominantly export-oriented and therefore more geographically concentrated port- and airport-centred distribution channels of horticulture and apparel, mobile phones are products that are sold in domestic as well as overseas markets. Hence, the characteristics of retailing and trade in emerging and developing economies become more important, as to understand the market idiosyncrasies requires local knowledge, which incumbent transport and logistics intermediaries can exploit to their advantage. Their knowledge of markets, retail channels and consumer preferences could provide a competitive advantage compared with foreign companies and, with remarkable growth rates in mobile phone usage, this should create substantial business opportunities. The diversity of distribution systems and the capabilities of local transport and logistics providers to serve fragmented markets - together with knowledge transfer through national and foreign mobile phone companies and retailers - thus might become a stepping stone to develop the competencies necessary to enter the 3PL market on the manufacturing, upstream side as well.

Second, the embedded nature of the mobile communications supply chain makes it difficult for incumbent logistics firms to enter the supply chain at the centre of mobile phone production, as OEM and first-tier suppliers tend to build long-term relationships with established transnational 3PLs. They provide all the services at the production location, in dedicated mobile communications clusters coordinated by firms like Nokia (see Liu et al. 2004) or Flextronics, with host-country providers considered to be lacking the capabilities and experience to be selected as major logistics partners. However, further down the GPN, involvement and related upgrading opportunities become more likely. This is for two reasons: first, as with the consumption end of the GPN, the upstream supply chain beyond the first tier is very fragmented (Catalan and Kotzab 2003: 673), leading to similar competitive advantages as outlined above. Second, the mobile communications sector still shows strong involvement of the state, despite de-regulation and liberalization, which often results in specific procurement policies for materials and services (for a case study of Malaysia, see Sharif et al. 2009).

\section{Conclusion}

This working paper has attempted to provide a structured account of the role of logistics in GPNs and its potential for economic and social upgrading. In the first part of the paper, we looked at logistics as an industry in its own right; in later sections we looked at intersections with the other sectors under study in the CtG programme. It has quickly become clear that our knowledge of the developmental impacts of logistics is limited, that logistics is an under-researched area and that evidence so far is very patchy. In particular, four areas where further academic research is required can be highlighted (see Coe 2013 for a more detailed discussion): first, changing corporate strategies and intra-industrial upgrading in the logistics sector; second, the changing regulatory institutional context within which logistics firms operate, at various scales; third, the dynamics of social upgrading and downgrading accompanying the 'logistics revolution'; and fourth, the potential for upgrading in the client sectors served by the global logistics industry. But what has become clear is that logistics have gained increasing importance for processes of value creation, enhancement and capture by both domestic firms and foreign investors. Logistics provide opportunities for new firm formation and employment growth, technological and organizational learning, improved skills and wage growth. 
Far from simply being a derived demand by manufacturers and service providers in GPNs, the logistics industry has seen a dynamic and substantial transformation. In the wake of increased outsourcing and ongoing value chain fragmentation, the task of coordinating and handling the global flows of materials and information has led to a highly differentiated landscape of logistics provision that - including transport activities - today positions the sector among the largest in terms of global employment, accounting for an estimated 5 percent of the workforce in many countries of the Global North as well as the Global South. Beyond a growing number of logisticsrelated jobs, this transformation has created a labour market that is bifurcated, reflecting on the one hand the growing need for skilled workers to operate in a sector that is partly driven by technological innovation and sophisticated divisions of labour, and on the other hand a large workforce segment that is highly gendered and characterized by low skills, low wages, contingency, insecurity and racialization. Consequently, the 'logistics revolution' has produced and continues to produce variegated outcomes in terms of economic and social upgrading.

Adequate transport and logistics infrastructures are among the crucial prerequisites for national economies in the pursuit of economic upgrading and growth, along with other relevant factors that have an impact on economic exchange and investment, such as the efficiency of customs clearance, the quality of logistics services and the reliability of timely deliveries. Combining such factors in the LPI - while not unproblematic - has helped render visible the problems many countries still face on the 'high road' to economic development. What is more, the geographically uneven provision of quality infrastructure and logistics services often contributes to substantial regional inequalities in terms of economic upgrading opportunities. The same is true at the industry and firm levels, where the implementation of sophisticated technology like EDI, RFID and other forms of managing supply chains can help include actors with the capabilities to implement such systems while clearly excluding others that lack such capabilities. This is an issue not only for logistics firms but also for firms in client sectors such as horticulture, apparel and mobile communications, as illustrated earlier in this paper. Against this backdrop, the role of the state in regulating transport and logistics systems is central in order to mitigate against the negative and geographically uneven developmental consequences of selective infrastructure, logistics and skills investment in a neoliberal global economy.

As with economic upgrading, the opportunities and challenges for social upgrading in the logistics industry and client sectors are variegated and contingent. Despite the creation of new jobs in GPNs that are based on managing technologically complex systems and require a high degree of skills, a 'low-road' labour market model continues to exist, with many commentators arguing that this model has become even more prevalent in recent times. In this paper, we have outlined the various dimensions of social upgrading and downgrading in global logistics in the context of GPN development. The picture painted by this analysis is still rather bleak, given the struggles of a large proportion of transport logistics workers to secure labour rights, decent wages and working conditions. But the crucial role that transport and logistics today play in connecting firms and economies through GPNs also offers new opportunities for workers' agency to try and improve their lot, especially in places where the material flows of GPNs converge. The emergence of logistics clusters (such as ports, airports and agglomerations of DCs, for instance) as a spatial expression of the 'logistics revolution' - combining a growing number of different actors and functions within GPNs in one place - has also amplified the potential of these geographical nodes in GPNs to be 'choke points' where interruptions of their operations can affect global production, trade and consumption in serious ways. This means logistics workers in these places have the potential to bring to a halt not only their own business operations but also a wider range of global 
value chains that connect through these clusters, thus finding new levers to bring about social upgrading in logistics and GPN. 


\section{References}

Abernathy, F., Volpe, A. and Weil, D. (2006). 'The future of the apparel and textile industries: Prospects and choices for public and private actors'. Environment and Planning A 38: 2207-2232.

Abernathy, F. H., Dunlop, J., Hammond, J. H. and Weil, D. (1999). A Stitch in Time: Lean Retailing and the Transformation of Manufacturing. New York: Oxford University Press.

Almotairi, B. and Lumsden, K. (2009). 'Port logistics platform integration in supply chain management'. International Journal of Shipping and Transport Logistics 1(2): 194-210.

Angeles, R. (2005). 'Rfid technologies: Supply-chain applications and implementation issues'. Information Systems Management 22(1): 51-65.

Antonio, E. and Rodolfo, M. (2006). 'Assessment of competitiveness and logistics infrastructure of the Philippine garments industry'. Discussion Paper 2006-08. Makati City: PIDS.

Aoyama, Y. and Ratick, S. J. (2007). 'Trust, transactions, and information technologies in the US logistics industry'. Economic Geography 83(2): 159-180.

Aoyama, Y., Ratick, S. and Schwarz, G. (2005). 'Modelling the impact of business-to-business electronic commerce on the organization of the logistics industry'. Geographical Analysis 37(1): 4668.

Aoyama, Y., Ratick, S. and Schwarz, G. (2006). 'Organizational dynamics of the US logistics industry: An economic geography perspective'. Professional Geographer 58(3): 330-343.

Arvis, J.-F., Mustra, M., Ojala, L., Shepherd, B. and Saslavsky, D. (2012). Connecting to Compete 2012: Trade Logistics in the Global Economy. Washington, DC: World Bank.

Babu, S. C. (2007). 'Presentation'. Sixth AFIT Conference, Tokyo, 22-23 October.

Bensman, D. (2008). 'Globalization and the Labour Markets of the Logistics Industry'. Sloan Industry Studies Conference, Boston, MA, 2 May.

Berglund, M., van Laarhoven, P., Sharman, G. and Wandel, S. (1999). 'Third-party logistics: Is there a future?' International Journal of Logistics Management 10(1): 59-82.

Bichou, K. and Gray, R. (2004). 'A logistics and supply chain management approach to port performance measurement'. Maritime Policy \& Management 31(1): 47-67.

Bonacich, E. (2005). 'Labor and the global logistics revolution', in R. Appelbaum and W. Robinson (eds). Critical Globalisation Studies. New York: Routledge.

Bonacich, E. and de Lara, J. (2009). 'Economic crisis and the logistics industry: Financial insecurity for warehouse workers in the Inland Empire'. Working Paper 2009-13. Los Angeles, CA: UCLA/IRLE.

Bonacich, E. and Wilson, J. B. (2008). Getting the Goods: Ports, Labor and the Logistics Revolution. Ithaca, NY: Cornell University Press.

Boschma, R. A. and Lambooy, J. G. (2004). 'A dynamic transaction cost perspective on fourth party logistic service development'. Mimeo.

Bowen, J. and Leinbach, T. (2004). 'Market concentration in the air freight forwarding industry'. Tijdschrift voor Economische en Sociale Geografie 95: 174-188.

Bowen, J. T. and Leinbach, T. R. (2006). 'Global production networks and competitive advantage: Air freight services and the electronics industry in Southeast Asia'. Economic Geography 82(2): 147-166. 
Braithwaite, J. and Drahos, P. (2000). Global Business Regulation. Cambridge: Cambridge University Press.

Carter, C. R. and Jennings, M. M. (2002). 'Logistics social responsibility: An integrative framework'. Journal of Business Logistics 23(1): 145-180.

Catalan, M. and Kotzab, H. (2003). 'Assessing the responsiveness in the Danish mobile phone supply chain'. International Journal of Physical Distribution \& Logistics Management 33(8): 668686.

Chandra, P. and Jain, N. (2009). 'The logistics sector in India: Overview and challenges', in J.M. Swaminatham (ed.). Indian Economic Superpower: Fiction or Future. Singapore: World Scientific Publishing.

Chopra, S. and Meindl, P. (2009). Supply Chain Management: Strategy, Planning and Operation. Fourth edition. Harlow: Pearson.

Christopher, M. (2005). Logistics and Supply Chain Management. Third edition. Harlow: Pearson.

Christopher, M., Lowson, B. and Peck, H. (2004). 'Fashion logistics and quick response', in J. Fernie and L. Sparks (eds.). Logistics and Retail Management. London: Kogan Page. .

Ciliberti, F., Pontrandolfo, P. and Scozzi, B. (2008). 'Logistics social responsibility: Standard adoption and practices in Italian companies'. International Journal of Production Economics 113: 88-106.

Coe, N. M. (2013). 'Missing links: Logistics, governance and upgrading in a shifting global economy'. Review of International Political Economy, in press.

Coe, N. M., Dicken, P. and Hess, M. (2008). 'Global production networks: Realizing the potential'. Journal of Economic Geography 8(3): 271-295.

Coe, N. M., Hess, M., Yeung, H. W. C., Dicken, P. and Henderson, J. (2004). 'Globalizing regional development: A global production networks perspective'. Transactions of the Institute of British Geographers 29(4): 468-484.

Coe, N. M., Kelly, P. and Yeung, H. W. C. (2013). Economic Geography: A Contemporary Introduction. Second edition. Malden/Oxford: Blackwell.

CSIR (Council for Scientific and Industrial Research) (2009). 'The sixth annual state of logistics survey for South Africa 2009'. Pretoria: CSIR.

Danskin, P., Englis, B., Solomon, M., Goldsmith, M. and Davey, J. (2005). 'Knowledge management as competitive advantage: Lessons from the textile and apparel value chain'. Journal of Knowledge Management 9(2): 91-102.

Dicken, P. (2007). Global Shift. Fifth edition. London: Sage.

Dicken, P. (2011). Global Shift. Sixth edition. London: Sage.

Dornier, P.-P., Ernst, R., Fender, M. and Kouvelis, P. (1998). Global Operations: Management and Logistics. Chichester: Wiley.

Drumwright, M. (1994). 'Company advertising with a social dimension: The role of non-economic criteria'. Journal of Marketing 60(4): 71-87.

Erker, P. (2008). The Dachser Logistics Company: Global Competition and the Strength of the Family Business. Frankfurt am Main: Campus.

Fernie, J. and Sparks, L. (2004) (eds) Logistics and Retail Management. Second edition. London: Kogan Page. 
Fernie, J. and McKinnon, A. (2004). 'The development of e-tail logistics', in J. Fernie and L. Sparks (eds). Logistics and Retail Management. London: Kogan Page.

Fowler, C. S. (2006). 'Re-exploring transport geography and networks: A case study of container shipments to the West Coast of the United States'. Environment and Planning A 38(8): 1429-1448.

Fransman, M. (2002). Telecoms in the Internet Age. From Boom to Bust to ...? Oxford: Oxford University Press.

Gereffi, G. (2001). 'Shifting governance structures in global commodity chains, with special reference to the Internet'. American Behavioural Scientist 44: 1616-1637.

Gereffi, G. (1999). 'International trade and industrial upgrading in the apparel commodity chain'. Journal of International Economics 48: 37-70.

Gereffi, G. and Memedovic, O. (2003). The Global Apparel Value Chain: What Prospects for Upgrading by Developing Countries? Vienna: UNIDO.

Gereffi, G., Humphrey, J. and Sturgeon, T. (2005). 'The governance of global value chains'. Review of International Political Economy 12: 78-104.

Goetz, A. and Rodrigue, J.-P. (1999). 'Transport terminals: New perspectives'. Journal of Transport Geography 7: 237-240.

Hall, J. and Matos, S. (2010). 'Incorporating impoverished communities in sustainable supply chains'. International Journal of Physical Distribution \& Logistics Management 40(1/2): 124-147.

Hall, P., Hesse, M. and Rodrigue, J.-P. (2006). 'Re-exploring the interface between economic and transport geography'. Environment \& Planning A 38(8): 1401-1408.

Harrison, A., Christopher, M. and van Hoek, R. (1999). Creating the Agile Supply Chain. Corby: Institute of Logistics and Transport.

Henderson, J., Dicken, P., Hess, M., Coe, N. and Yeung, H. W. C. (2002). 'Global production networks and the analysis of regional development'. Review of International Political Economy 9(3): 436-464.

Hess, M. and Coe, N. M. (2006). 'Making connections: Global production networks, standards, and embeddedness in the mobile telecommunications industry'. Environment and Planning $A$ 38(7): 1205-1227.

Hess, M. and Yeung, H. W. C. (2006). 'Whither global production networks in economic geography? Past, present, and future'. Guest editorial. Environment and Planning A 38(7): 11931204.

Hesse, M. (2008). The City as a Terminal: The Urban Context of Logistics and Freight Transport. Aldershot: Ashgate.

Hesse, M. and Rodrigue, J.-P. (2004). 'The transport geography of logistics and freight distribution'. Journal of Transport Geography 12(3): 171-184.

Hesse, M. and Rodrigue, J.-P. (2006). 'Global production networks and the role of logistics and transportation'. Growth and Change 37(4): 499-509.

Higginson, J. and Bookbinder, J. (2005). 'Distribution centres in supply chain operations', in A. Langevin and D. Riopel (eds.). Logistics Systems: Design and Optimization. New York: Kogan Page.

ILO (International Labour Organization) (2004). The Global Seafarer: Living and Working Conditions in a Globalized Industry. Geneva: ILO. 
ITF (International Transport Workers Federation) (2006). 'Reaching out to informal workers'. Transport International Magazine 24 (July).

Joosten, F. (2007). 'Development strategy for the export-oriented horticulture in Ethiopia'. Wageningen: University of Wageningen.

Kenney, M. and Curry, J. (2001). 'Beyond transaction costs: e-commerce and the power of Internet dataspace', in T. Leinbach and S. D. Brunn (eds.). Worlds of e-commerce: Economic, Geographical, and Social Dimensions. Chichester: Wiley.

Knowles, R. D. (2009). 'Transport geography', in R. Kitchin and N.J. Thrift (eds). International Encyclopaedia of Human Geography. Oxford: Elsevier.

Korsten, L., Njie, D. and Sivakumar, D. (2008). Horticultural Chain Management for Eastern and Southern Africa: A Theoretical Manual. London: Commonwealth Secretariat.

Kuehne and Nagel (2009). 'Flowers from Mount Kenya'. World Magazine 2/09, 12-13.

Lee, J. and Gereffi, G. (2013). 'The co-evolution of concentration in mobile phone global value chains and its impact on social upgrading in developing countries'. Capturing the Gains Working Paper 2013/25.

LEI (Agricultural Economics Research Institute, Wageningen) (n.d.). 'Ghana: Sustainable horticultural export chain'. Wageningen: LEI.

Leinbach, T. (2001). 'Emergence of the digital economy and e-commerce', in T. Leinbach and S.D. Brunn (eds). Worlds of e-commerce: Economic, Geographical, and Social Dimensions. Chichester: Wiley.

Leinbach, T. and Bowen, J. (2004). 'Air cargo services and the electronics industry in Southeast Asia'. Journal of Economic Geography 4: 299-321.

Levinson, M. (2006). The Box: How the Shipping Container Made the World Smaller and the World Economy Bigger. Princeton, NJ: Princeton University Press.

Li, F., Whalley, J. and Williams, H. (2001). 'Between physical and electronic spaces: The implications for organizations in the networked economy'. Environment and Planning A 33: 699716.

Liu, W., Dicken P. and Yeung, H. W. C. (2004). 'New information and communication technologies and local clustering of firms: A case study of the Xingwang Industrial Park in Beijing'. Urban Geography 25(4): 390-407.

Martin, B. (2008). 'Globalisation on wheels'. ITF: mimeo.

Mei, Z. and Dinwoodie, J. (2005). 'Electronic shipping documentation in China's international supply chains'. Supply Chain Management 10(3): 198-205.

Milberg, W. and Winkler, D. (2010). 'Economic and social upgrading in global production networks: Problems of theory and measurement'. Capturing the Gains Working Paper 2010/04.

Mintsis, G., Basbas, S., Papaioannou, P., Taxiltaris, C. and Tziavos, I. N. (2004). 'Applications of GPS technology in the land transportation system'. European Journal of Operational Research 152(2): 399-409.

Moodley, S. (2003). 'The challenge of e-business for the South African apparel sector'. Technovation 23(7): 557-570. 
Notteboom, T. and Rodrigue, J.-P. (2008). 'Containerization, box logistics and global supply chains: The integration of ports and liner shipping networks'. Maritime Economics \& Logistics 10(12): $152-174$.

Ojala, L., Andersson, D. and Naula, T. (2008). 'Linking to global value chains: An imperative for developing countries'. International Journal of Technological Learning, Innovation and Development 1(3): 427-450.

O‘Connor, K. (2009). 'Transport and globalization', in R. Kitchin and N.J. Thrift (eds). International Encyclopaedia of Human Geography. Oxford: Elsevier.

Olsen \& Sons Advertising (n.d.). 'Unitrans services "bundled" for success at Dwangwa in Malawi'. KwaZulu-Natal: Olsen \& Sons Advertising.

Rodrigue, J-P. (2006a). 'Challenging the derived transport demand thesis: Geographical issues in freight distribution'. Environment and Planning A 38(8): 1449-1462.

Rodrigue, J-P. (2006b). 'Transportation and the geographical and functional integration of global production networks'. Growth and Change 37(4): 510-525.

Rodrigue, J.-P. (2008). 'The thruport concept and transmodal rail freight distribution in North America'. Journal of Transport Geography 16(4): 233-246.

Rodrigue, J.-P., Comtois, C. and Slack, B. (2006). The Geography of Transport Systems. Second edition. London: Routledge.

Rushton, A. and Walker, S. (2007). International Logistics and Supply Chain Outsourcing. London: Kogan Page.

Sachan, A. and Datta, S. (2005). 'Review of supply chain management and logistics research'. International Journal of Physical Distribution \& Logistics Management 35(9): 664-705.

Schrank, A. (2004). 'Ready-to-wear development? Foreign investment, technology transfer, and learning by watching in the apparel trade'. Social Forces 83(1): 123-156.

Schwarz, G. (2006). 'Enabling global trade above the clouds: Restructuring processes and information technology in the transatlantic air-cargo industry'. Environment and Planning A 38(8): 1463-1485.

Seuring, S., Sarkis, J., Müller, M. and Rao, P. (2008). 'Sustainability and supply chain management - an introduction to the special issue', Journal of Cleaner Production 16(15): 15451551.

Sharif, A., Rahim, S., Gallear, D. and Irani, Z. (2009). 'A supplier selection strategy within the Malaysian telecommunications industry'. International Logistics and Supply Chain Congress, Istanbul, 5-6 November.

Sheffi, Y. (2012). Logistics Clusters. Delivering Value and Driving Growth. Cambridge, MA: MIT Press.

Skjøtt-Larsen, T., Schary, P. B, Mikkola, J. and Kotzab, H. (2007). Managing the Global Supply Chain. Third edition. Copenhagen: Copenhagen Business School Press.

Smith, D. and Sparks, L. (2004). 'Temperature-controlled supply chains', in J. Fernie and L. Sparks (eds). Logistics and Retail Management. London: Kogan Page.

Sparks, L. and Wagner, B. (2004). 'Transforming technologies: Retail exchanges and RFID', in J. Fernie and L. Sparks (eds.). Logistics and Retail Management. London: Kogan Page.

Stopford, M. (2009). Maritime Economics. London: Routledge. 
Turnbull, P. (2000). 'Contesting globalization on the waterfront'. Politics and Society 28(3): 367391.

Turnbull, P. and Wass, V. J. (2007). 'Defending dock workers: Globalization and labor relations in the world's ports'. Industrial Relations 46(3): 582-612.

Vagneron, I., Faure, G. and Loeillet, D. (2009). 'Is there a pilot in the chain? Identifying the key drivers of change in the fresh pineapple sector'. Food Policy 34: 437-446.

van Egeraat, C. and Jacobson, D. (2005). 'Geography of production linkages in the Irish and Scottish Microcomputer industry: The role of logistics'. Economic Geography 81(3): 283-303.

Voortman, C. (2004). Global Logistics Management. Claremont: Juta Academic.

Wang, J. J. and Olivier, D. (2006). 'Port - FEZ bundles as spaces of global articulation: The case of Tianjin, China'. Environment and Planning A 38(8): 1487-1503.

Wang, J., Olivier, D., Notteboom, T. and Slack, B. (2007) (eds.). Ports, Cities, and Global Supply Chains. Aldershot: Ashgate.

Waters, D. (2010) (ed.). Global Logistics: New Directions in Supply Chain Management. Sixth edition. London: Kogan Page.

Wood, D. F., Barone, A. P., Murphy, P. R. and Wardlow, D. L. (2002). International Logistics. Second edition. New York: Amacom. 
Appendix 1: Logistics Performance Index 2012

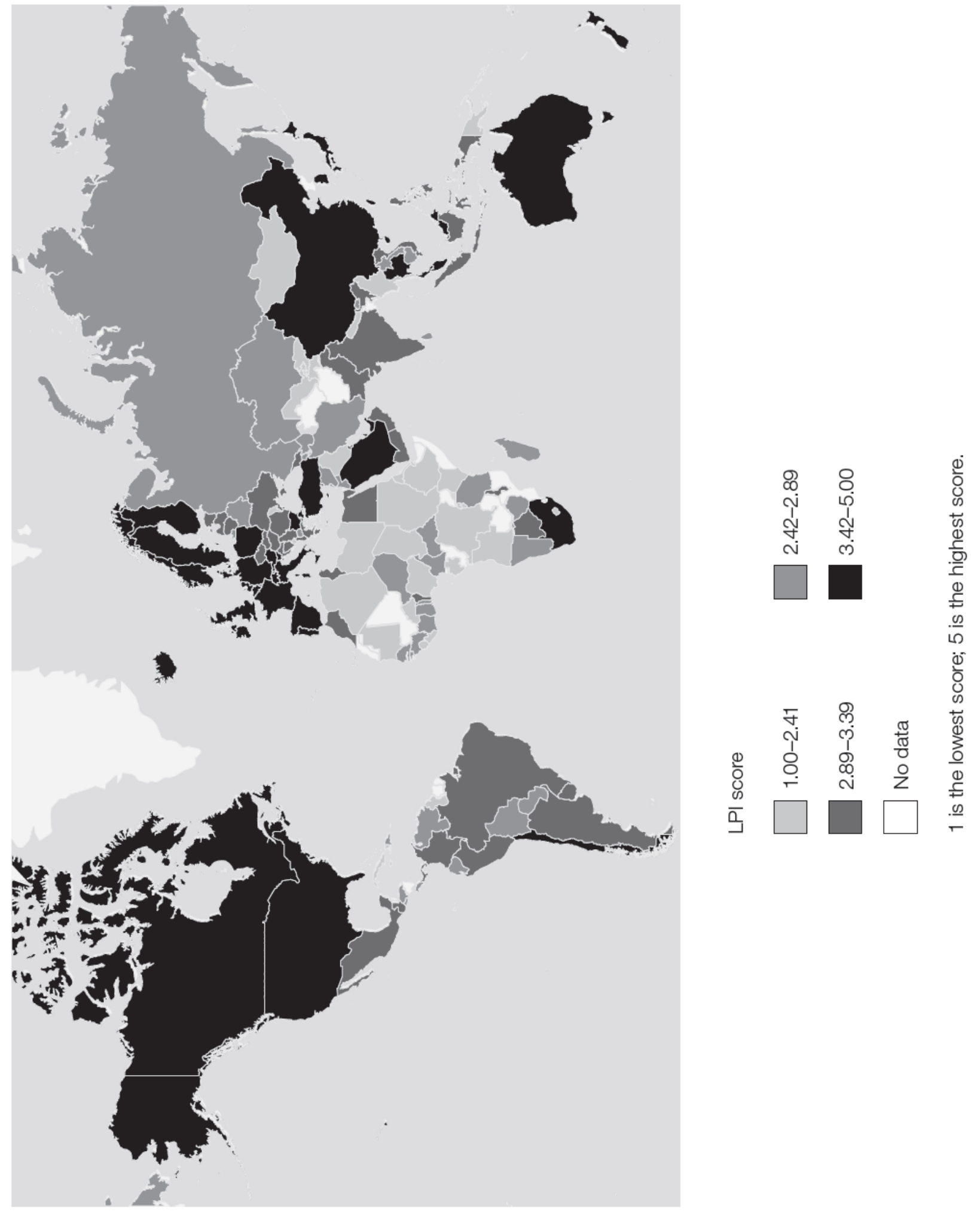

Source: Arvis et al. (2012), ii. 
Appendix 2: Top and bottom logistics performers, 2012

Table 1.1 The top 10 performers on the 2012 LPI

\begin{tabular}{|c|c|c|c|c|c|c|c|c|c|}
\hline \multirow[b]{2}{*}{ Economy } & \multicolumn{3}{|c|}{2012} & \multicolumn{3}{|c|}{2010} & \multicolumn{3}{|c|}{2007} \\
\hline & $\begin{array}{l}\text { LPI } \\
\text { rank }\end{array}$ & $\begin{array}{l}\text { LPI } \\
\text { score }\end{array}$ & $\begin{array}{c}\% \text { of } \\
\text { highest } \\
\text { performer }\end{array}$ & $\begin{array}{l}\text { LPI } \\
\text { rank }\end{array}$ & $\begin{array}{l}\text { LPI } \\
\text { score }\end{array}$ & $\begin{array}{c}\% \text { of } \\
\text { highest } \\
\text { performer }\end{array}$ & $\begin{array}{l}\text { LPI } \\
\text { rank }\end{array}$ & $\begin{array}{l}\text { LPI } \\
\text { score }\end{array}$ & $\begin{array}{c}\% \text { of } \\
\text { highest } \\
\text { performer }\end{array}$ \\
\hline Singapore & 1 & 4.13 & 100.0 & 2 & 4.09 & 99.2 & 1 & 4.19 & 100.0 \\
\hline Hong Kong SAR, China & 2 & 4.12 & 99.9 & 13 & 3.88 & 92.4 & 8 & 4.00 & 94.1 \\
\hline Finland & 3 & 4.05 & 97.6 & 12 & 3.89 & 92.6 & 15 & 3.82 & 88.3 \\
\hline Germany & 4 & 4.03 & 97.0 & 1 & 4.11 & 100.0 & 3 & 4.10 & 97.1 \\
\hline Netherlands & 5 & 4.02 & 96.7 & 4 & 4.07 & 98.5 & 2 & 4.18 & 99.6 \\
\hline Denmark & 6 & 4.02 & 96.6 & 16 & 3.85 & 91.4 & 13 & 3.86 & 89.6 \\
\hline Belgium & 7 & 3.98 & 95.3 & 9 & 3.94 & 94.5 & 12 & 3.89 & 90.7 \\
\hline Japan & 8 & 3.93 & 93.8 & 7 & 3.97 & 95.2 & 6 & 4.02 & 94.8 \\
\hline United States & 9 & 3.93 & 93.7 & 15 & 3.86 & 91.7 & 14 & 3.84 & 89.1 \\
\hline United Kingdom & 10 & 3.90 & 92.7 & 8 & 3.95 & 94.9 & 9 & 3.99 & 93.8 \\
\hline
\end{tabular}

Source: Logistics Performance Index 2007, 2010, and 2012.

Table 1.2 The bottom 10 performers on the 2012 LPI

\begin{tabular}{|c|c|c|c|c|c|c|c|c|c|}
\hline \multirow[b]{2}{*}{ Economy } & \multicolumn{3}{|c|}{2012} & \multicolumn{3}{|c|}{2010} & \multicolumn{3}{|c|}{2007} \\
\hline & $\begin{array}{l}\text { LPI } \\
\text { rank }\end{array}$ & $\begin{array}{l}\text { LPI } \\
\text { score }\end{array}$ & $\begin{array}{c}\% \text { of } \\
\text { highest } \\
\text { performer }\end{array}$ & $\begin{array}{l}\text { LPI } \\
\text { rank }\end{array}$ & $\begin{array}{l}\text { LPI } \\
\text { score }\end{array}$ & $\begin{array}{c}\% \text { of } \\
\text { highest } \\
\text { performer }\end{array}$ & $\begin{array}{c}\text { LPI } \\
\text { rank }\end{array}$ & $\begin{array}{l}\text { LPI } \\
\text { score }\end{array}$ & $\begin{array}{c}\% \text { of } \\
\text { highest } \\
\text { performer }\end{array}$ \\
\hline Comoros & 146 & 2.14 & 36.5 & 120 & 2.45 & 46.5 & 85 & 2.48 & 46.3 \\
\hline Eritrea & 147 & 2.11 & 35.5 & 154 & 1.70 & 22.4 & 124 & 2.19 & 37.2 \\
\hline Sudan & 148 & 2.10 & 35.3 & 146 & 2.21 & 38.7 & 64 & 2.71 & 53.6 \\
\hline Congo, Rep. & 149 & 2.08 & 34.7 & 116 & 2.48 & 47.4 & na & na & na \\
\hline Sierra Leone & 150 & 2.08 & 34.5 & 153 & 1.97 & 31.2 & 144 & 1.95 & 29.9 \\
\hline Nepal & 151 & 2.04 & 33.1 & 147 & 2.20 & 38.6 & 130 & 2.14 & 35.7 \\
\hline Chad & 152 & 2.03 & 32.9 & 115 & 2.49 & 47.9 & 142 & 1.98 & 30.8 \\
\hline Haiti & 153 & 2.03 & 32.8 & 98 & 2.59 & 51.1 & 123 & 2.21 & 38.0 \\
\hline Djibouti & 154 & 1.80 & 25.5 & 126 & 2.39 & 44.8 & 145 & 1.94 & 29.5 \\
\hline Burundi & 155 & 1.61 & 19.5 & na & na & na & 113 & 2.29 & 40.4 \\
\hline
\end{tabular}

na is not applicable.

Source: Logistics Performance Index 2007, 2010, and 2012.

Table 1.3 The top 10 upper middle-income performers on the 2012 LPI

\begin{tabular}{|c|c|c|c|c|c|c|c|c|c|}
\hline \multirow[b]{2}{*}{ Economy } & \multicolumn{3}{|c|}{2012} & \multicolumn{3}{|c|}{2010} & \multicolumn{3}{|c|}{2007} \\
\hline & $\begin{array}{c}\text { LPI } \\
\text { rank }\end{array}$ & $\begin{array}{l}\text { LPI } \\
\text { score }\end{array}$ & $\begin{array}{c}\% \text { of } \\
\text { highest } \\
\text { performer }\end{array}$ & $\begin{array}{l}\text { LPI } \\
\text { rank }\end{array}$ & $\begin{array}{l}\text { LPI } \\
\text { score }\end{array}$ & $\begin{array}{c}\% \text { of } \\
\text { highest } \\
\text { performer }\end{array}$ & $\begin{array}{c}\mathrm{LPI} \\
\text { rank }\end{array}$ & $\begin{array}{l}\text { LPI } \\
\text { score }\end{array}$ & $\begin{array}{c}\% \text { of } \\
\text { highest } \\
\text { performer }\end{array}$ \\
\hline South Africa & 23 & 3.67 & 85.5 & 28 & 3.46 & 78.9 & 24 & 3.53 & 79.4 \\
\hline China & 26 & 3.52 & 80.5 & 27 & 3.49 & 79.9 & 30 & 3.32 & 72.8 \\
\hline Turkey & 27 & 3.51 & 80.3 & 39 & 3.22 & 71.4 & 34 & 3.15 & 67.5 \\
\hline Malaysia & 29 & 3.49 & 79.8 & 29 & 3.44 & 78.4 & 27 & 3.48 & 77.7 \\
\hline Bulgaria & 36 & 3.21 & 70.7 & 63 & 2.83 & 58.8 & 55 & 2.87 & 58.6 \\
\hline Thailand & 38 & 3.18 & 69.6 & 35 & 3.29 & 73.6 & 31 & 3.31 & 72.5 \\
\hline Chile & 39 & 3.17 & 69.5 & 49 & 3.09 & 67.3 & 32 & 3.25 & 70.5 \\
\hline Tunisia & 41 & 3.17 & 69.4 & 61 & 2.84 & 58.9 & 60 & 2.76 & 55.3 \\
\hline Brazil & 45 & 3.13 & 68.2 & 41 & 3.20 & 70.6 & 61 & 2.75 & 54.9 \\
\hline Mexico & 47 & 3.06 & 66.0 & 50 & 3.05 & 65.7 & 56 & 2.87 & 58.6 \\
\hline
\end{tabular}

Source: Logistics Performance Index 2007, 2010, and 2012.

Source: Arvis et al. (2012), 8. 


\section{CAPTURING THE GAINS}
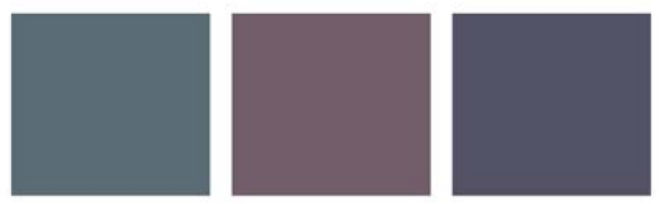

economic and social upgrading in global production networks

\section{Published by:}

Capturing the Gains

The University of Manchester

Arthur Lewis Building

Oxford Road

Manchester

M13 9PL

United Kingdom

capturingthegains@manchester.ac.uk

www.capturingthegains.org
Capturing the Gains brings together an international network of experts from North and South. The research programme is designed to engage and influence actors in the private sector, civil society, government and multi-lateral organizations. It aims to promote strategies for decent work in global production networks and for fairer international trade. 